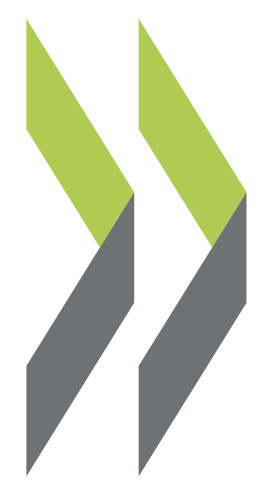

OECD Social, Employment and Migration Working Papers No. 103

\title{
Reforming Policies on Foreign Workers in Israel
}

\section{Adriana Kemp}


Organisation de Coopération et de Développement Économiques

Organisation for Economic Co-operation and Development

19-Mar-2010

DIRECTORATE FOR EMPLOYMENT, LABOUR AND SOCIAL AFFAIRS

English - Or. English

EMPLOYMENT, LABOUR AND SOCIAL AFFAIRS COMMITTEE

OECD SOCIAL, EMPLOYMENT AND MIGRATION WORKING PAPERS NO. 103

Reforming policies on foreign workers in Israel

by Adriana Kemp

JEL Classification: F22, O15.

KEYWORDS: foreign workers scheme; Israel; binding system; elderly home-care; "closed skies"; human trafficking; private brokers; Palestinian non-citizen workers

All Social, Employment and Migration Working Papers are now available through OECD's Internet website at http://www.oecd.org/els

JT03280410

Document complet disponible sur OLIS dans son format d'origine

Complete document available on OLIS in its original format 


\title{
DIRECTORATE FOR EMPLOYMENT, LABOUR AND SOCIAL AFFAIRS
}

www.oecd.org/els

\section{OECD SOCIAL, EMPLOYMENT AND MIGRATION WORKING PAPERS}

\author{
www.oecd.org/els/workingpapers
}

This series is designed to make available to a wider readership selected labour market, social policy and migration studies prepared for use within the OECD. Authorship is usually collective, but principal writers are named. The papers are generally available only in their original language - English or French - with a summary in the other.

Comment on the series is welcome, and should be sent to the Directorate for Employment, Labour and Social Affairs, 2, rue André-Pascal, 75775 PARIS CEDEX 16, France.

The opinions expressed and arguments employed here are the responsibility of the author(s) and do not necessarily reflect those of the OECD.

Applications for permission to reproduce or translate all or part of this material should be made to:

\author{
Head of Publications Service \\ OECD \\ 2, rue André-Pascal \\ 75775 Paris, CEDEX 16 \\ France
}

Copyright OECD 2009 
DELSA/ELSA/WD/SEM(2010)3

\section{ACKNOWLEDGEMENTS}

The author would like to thank Nelly Kfir for her skillful and diligent assistance in the gathering of the data. 


\begin{abstract}
Since the early 1990s, Israel has enacted a managed migration scheme for low-skilled foreign workers. Originally designed to replace Palestinian cross-border workers from the Occupied Territories in the secondary labour market, in 2007 foreign workers comprised $8.7 \%$ of the private-sector labour force, $40 \%$ of them without permits. Foreign workers are employed in three major sectors: construction, agriculture and home-care for the elderly. The latter has become the largest and fastest-growing sector employing foreign workers, mainly women. The Israeli temporary labour migration scheme is characterised by a strong dependency of certain sectors on foreign workers; disengagement of governmental agencies from direct involvement in recruitment, inspection of work conditions, effective enforcement of labour laws, and provision of services for foreign workers; a strong emphasis on temporariness coupled with lengthy and sometimes indefinite extension of possible stay (up to 63 months and potentially more); and lastly, by an entrenched client politics that guides policies on quota setting, permit allocation and employer subsidies. Recent government decisions that seek to overcome the distorting effects of the scheme on the Israeli labour market, while tempering deep-rooted norms that violate workers' labour and human rights, are heading in the right direction. However, they are also destined to fail if the scheme is not substantially revised in all its parts rather than through a patchwork of focused and segmented measures.
\end{abstract}

\title{
RÉSUMÉ
}

Depuis le début des années 1990, Israël a promulgué un système de gestion de l'immigration des travailleurs étrangers peu qualifiés, initialement conçu pour remplacer les travailleurs transfrontaliers des territoires palestiniens, occupés dans le marché secondaire du travail. En 2007, les travailleurs étrangers représentaient $8,7 \%$ de la force de travail du secteur privé, dont $40 \%$ étaient en situation irrégulière. Les travailleurs étrangers sont employés principalement dans trois secteurs: le BTP, l'agriculture et les soins à domicile pour les personnes âgées. Ce dernier secteur est devenu le plus important et a connu la plus forte croissance de l'emploi des travailleurs étrangers, principalement des femmes. Le régime temporaire des migration de travail en Israël se caractérise par une forte dépendance de certains secteurs envers les travailleurs étrangers; un désengagement des organismes gouvernementaux dans le processus de recrutement, la surveillance des conditions de travail, l'exécution effective des réglementations du travail, et les services de soutien aux travailleurs étrangers ; l'accent mis sur le caractère temporaire du séjour, malgré les possibilités d'extension parfois infinies (jusqu'à 63 mois et plus) et, enfin, par une politique clientéliste persistante guidée par la fixation de quotas, l'attribution des permis et des subventions à l'employeur. Quelques décisions récentes du gouvernement visant à neutraliser les effets néfastes de ce système de gestion du marché du travail israélien, tout en tempérant les normes profondément enracinées qui violent les droits du travail et de l'homme, vont dans la bonne direction. Cependant, elles seront aussi vouées à l'échec si l'ensemble du système n'est pas sensiblement revu, à la place d'un patchwork de mesures ciblées et segmentées. 
The OECD Council decided to open accession discussions with Israel on 16 May 2007, and an Accession Roadmap, setting out the terms, conditions, and process for Accession was adopted on 30 November 2007 (see www.oecd.org search for "OECD Enlargement"). The OECD's Employment, Labour and Social Affairs Committee was requested to review Israel's labour Market and Social Polices and, as part of this process, prepared the OECD Review of Labour Market and Social Policies in Israel which was released in January 2010 (www.oecd.org/els/israel2010).

This publication covered a wide range of issues including: improving enforcement of labour laws; investing more in effective ALMPs, including welfare-to-work policies; strengthening the fight against discrimination; extending infrastructural investment in Arab localities; extending coverage of pension saving; new policies on foreign workers with temporary permits; and, policies to help absorb large quantities of permanent migrants.

The present paper was commissioned from Adriana Kemp, acting as a consultant to the OECD Secretariat in order to provide background information for the OECD review, but is not part of it. The views expressed in this paper cannot be attributed to the OECD or its Members; they are the responsibility of the authors alone.

Le Conseil de l'OCDE a décidé d'ouvrir des discussions avec Israël le 16 mai 2007 et une feuille de route, adoptée le 30 novembre 2007, définit les modalités, les conditions et le processus devant permettre à Israël d'adhérer à l'OCDE (voir www.oecd.org, recherchez sous "l'élargissement et l'engagement renforcée"). Le Comité de l'emploi, du travail et des affaires sociales de l'OCDE a été mandaté pour passer en revue le marché du travail et les politiques sociales d'Israël et, dans le cadre de ce processus, a préparé "l'examen des politiques sociales et du marché du travail d'Israël " qui a été publié en janvier 2010 (www.oecd.org/els/israel2010- en anglais seulement).

Cette publication couvre une vaste gamme de questions, notamment : améliorer l'application du droit du travail ; investir davantage dans des politiques actives du marché du travail qui soient plus efficaces et en particulier dans les mesures de réinsertion ; renforcer la lutte contre la discrimination ; accroître les investissements en infrastructures dans les localités arabes ; étendre la couverture du régime de retraite ; mettre en place un nouveau régime de permis temporaires pour les travailleurs étrangers et prendre des initiatives pour faciliter l'absorption d'un grand nombre de migrants permanents.

Ce rapport a été rédigé par Adriana Kemp, consultante au Secrétariat de l'OCDE, pour fournir les informations de base en vue de l'examen de l'OCDE, dont il ne fait pas toutefois partie intégrante. Les points de vue exprimés dans ce document ne peuvent être attribués à l'OCDE ou à ses membres ; ils sont de la responsabilité des seuls auteurs. 


\section{TABLE OF CONTENTS}

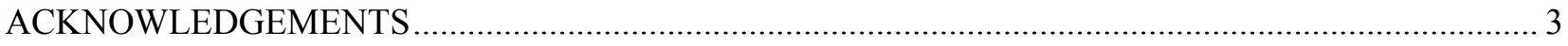

ABSTRACT …

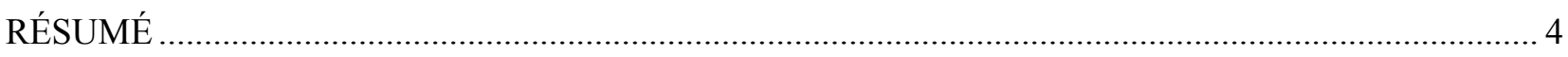

REFORMING POLICIES ON FOREIGN WORKERS IN ISRAEL .................................................... 7

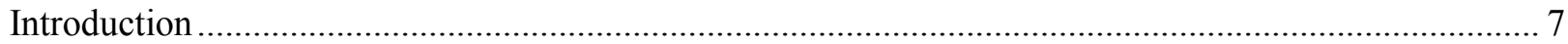

1. General information about foreign workers in Israel ..................................................................... 7

Trends in stocks and flows of labour migration and employment sectors.......................................... 7

Foreign workers with permits: Socio-demographic characteristics................................................ 10

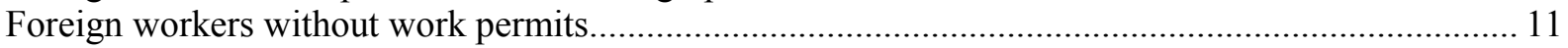

2. Labour migration and its impact on the Israeli labour force …...................................................... 14

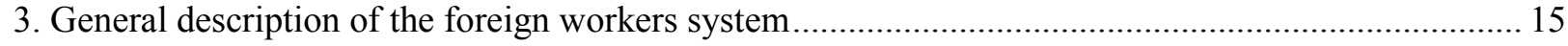

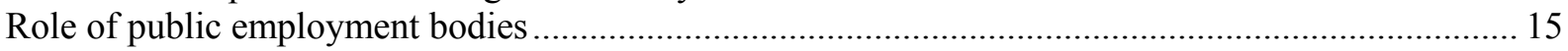

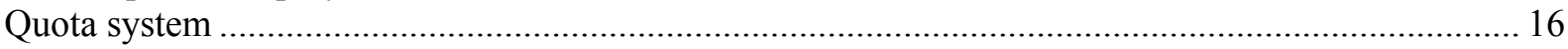

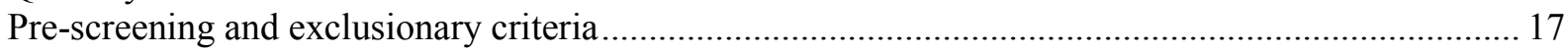

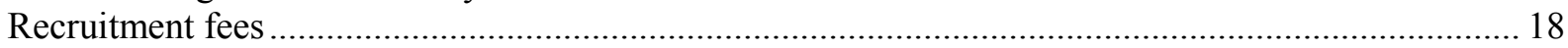

4. Policy issues: The Binding Policy and Human Trafficking ............................................................ 19

The Endorn Report and the new employment arrangement in the construction sector ........................ 20

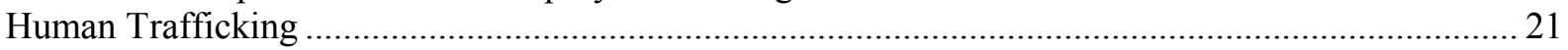

5. General employment conditions and access to social benefits....................................................... 21

Attempts to exclude foreign workers from their labour rights under the law ...................................... 23

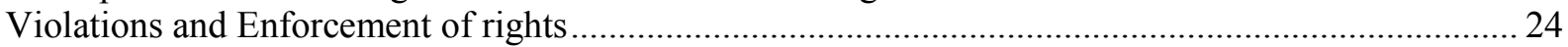

6. Inspection regime, deportation policy for irregulars and regularisation (amnesty) procedures ............ 26

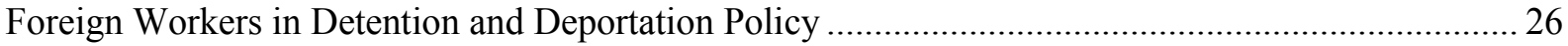

Pregnancy, Maternity and Children of Undocumented Foreign Workers ............................................ 27

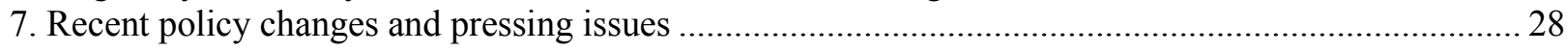

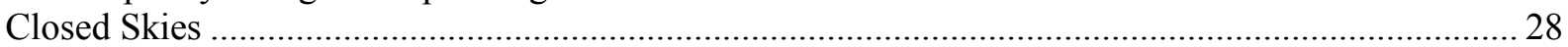

The following changes have not been fully implemented on the ground: .......................................... 29

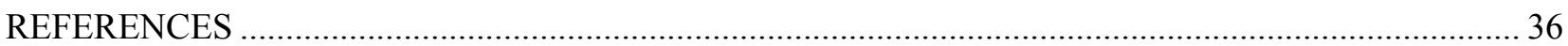

\section{Tables}

Table 1: Stock of overseas labour migrants (with and without permits) in Israel 2001-2007................... 8

Table 2: Stocks of foreign workers with permits in Israel 2001-2007 ............................................... 8

Table 3. Foreign workers with permits by main countries of origin/gender (end of 2007, in thousands) 10

Table 4. Foreign Workers Deported from Israel in 1995-2008.

\section{Figures}

Figure 1. Permits issued according to employment sectors 1996-2007 …............................................. 9

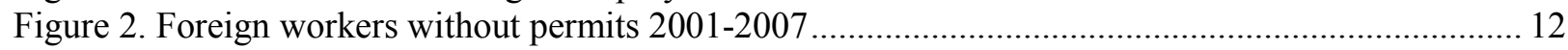




\section{REFORMING POLICIES ON FOREIGN WORKERS IN ISRAEL}

\section{Introduction}

1. In the early 1990 s, Israel enacted a managed migration scheme for low-skilled foreign workers ${ }^{1}$ to replace Palestinian commuters from the Occupied Territories in the Israeli secondary labour market. The deterioration of the political and security situation triggered by the 1987 intifada brought about a severe labor shortage in the construction and agriculture sectors, in which Palestinian workers had been concentrated since the early $1970 \mathrm{~s}^{2}{ }^{2}$ However, it was not until the Israeli government decided to seal the border with the occupied territories at the beginning of 1993 that a dynamics of ethnic replacement took place heralding the large-scale recruitment of foreign workers, primarily from Romania (construction sector) and Thailand (agriculture), and subsequently from other places. ${ }^{3}$ The distinctiveness of the Israeli labor migration scheme lies in that it was prompted not only by socio-economic considerations but also by geopolitical interests. These were linked to the articulation of a unilateral "separation" paradigm between Israelis and Palestinians that prevailed during the Oslo years, and that would become effective first within the secondary labor market where Palestinians had been unequally integrated since $1967 .^{4}$

2. Ever since 1993, the share of foreign workers in the Israeli labour market grew constantly and rapidly, outnumbering the highest level of Palestinian commuters ever in the Israeli labour force. In 2002, the number of foreign workers reached a peak of $11 \%$ of the total labour force $(13.8 \%$ of the labour force in the private sector), $60 \%$ of them without permits. In the same year, the Israeli government decided to "close the skies" to further recruitment of foreign labour with the aim to reduce significantly their numbers. The decision was part of a larger economic structural reform pushed by the Ministry of Finance and it aimed at replacing labor migrants with Israeli unemployed workers through the application of workfare policies and substantial cuts in welfare payments. ${ }^{5}$ While the "closed skies" policy succeeded in reducing the number of foreign workers - with and without permits - for a while, by 2007 their share in the labor market was again on the rise with an estimated $8.7 \%$ of the private-sector labour force. ${ }^{6}$ These figures rank Israel at the high end of the industrialised economies that are heavily dependent on foreign labour.

\section{General information about foreign workers in Israel}

\section{Trends in stocks and flows of labour migration and employment sectors}

3. The size of the foreign workers population at the end of 2007 was estimated at 200000,110000 of them with work permits. As illustrated in Table 1, the last decade has witnessed a decrease in the total number of foreign workers (with and without permits) staying in Israel.

\footnotetext{
${ }^{1}$ Unless otherwise specified, the term "foreign workers" refers to non-Palestinian labour migrants.

2 See Semyonov and Lewin-Epstein 1987.

${ }^{3}$ See Bartram 1998.

${ }^{4}$ See Kemp and Raijman 2008

${ }^{5}$ Ministry of Finance 2002.

${ }^{6}$ Central Bank of Israel (CBI) 2007: Figure E-3 Share of Foreign Workers and Palestinian Workers in Private Sector Labour Market 1997-2007, p. 191.
} 
Table 1: Stock of overseas labour migrants (with and without permits) in Israel 2001-2007

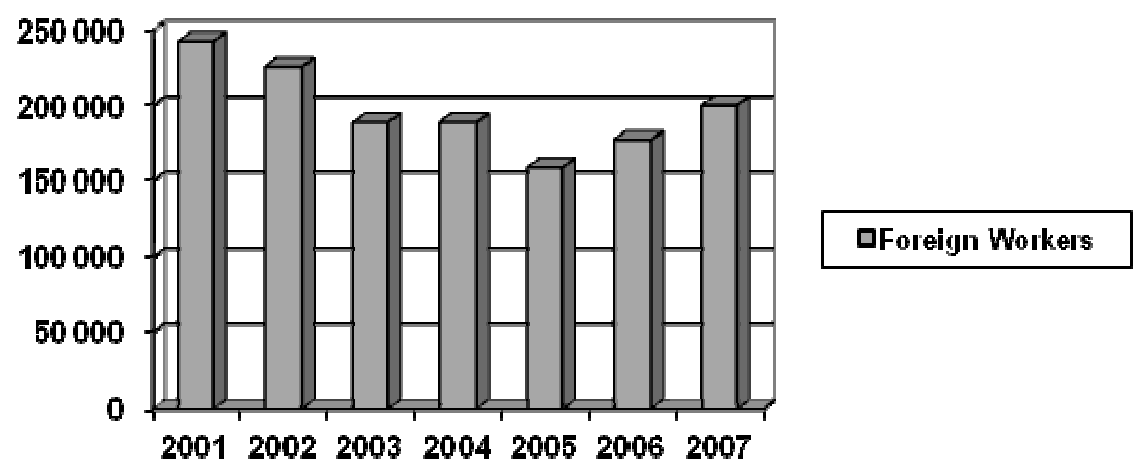

Data on 2005 (workers with permits) from Shaps 2007.

Data on 2006-2007 from Shaps 2008.

Source: Data until 2004 from Natan and Tzwebner 2009: Table 1.

4. As Table 2 shows, except for a brief respite in 2003-2005, since 2006 the stock of labour migrants with permits has been on the rise. The annual inflows of foreign workers entering Israel with permits have gradually increased, with $40 \%$ more entries in 2007 than in 2003 when they reached a low of $25100 .^{7}$

Table 2: Stocks of foreign workers with permits in Israel 2001-2007

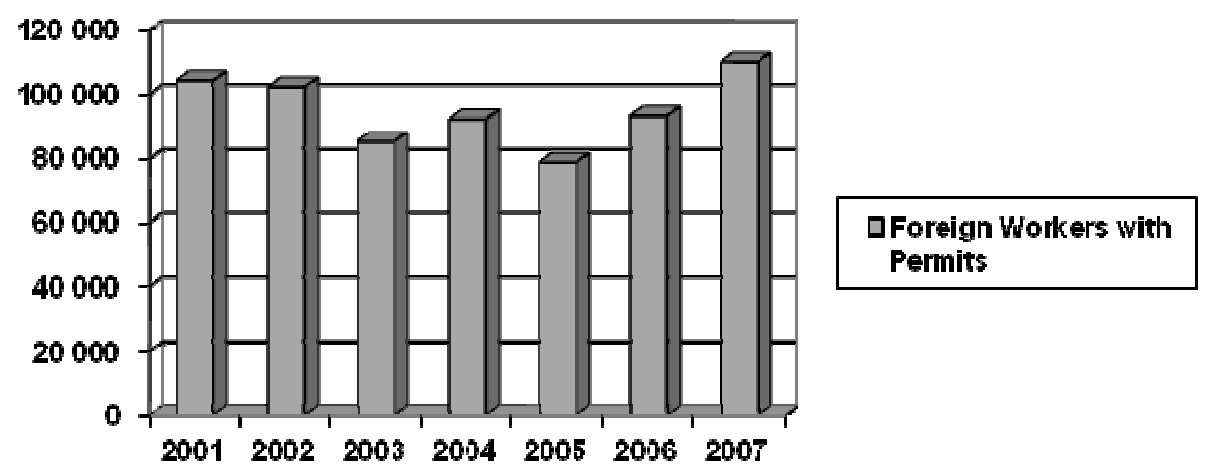

Source: Shaps 2008.

5. The increase in the stock of foreign workers with permits seems to indicate that the government is only partially upholding its declared policies. ${ }^{8}$ Seemingly, "Closing the skies" has had less impact on reducing the number of permits issued for new foreign workers than on diminishing the number of irregular migrants already within the country (see Section on Foreign Workers without permits). Second,

\footnotetext{
${ }^{7}$ The number of entries with permits in 2007 was 36,500 (Natan and Tzwebner 2009, Table 6).

${ }^{8}$ See CBI Report 2007, p. 193.
} 
governmental policies did not put an end to pressure from employers and manpower agencies but rather resulted in a "re-organisation" of the permits allocated to each employment sector (Figure 1).

Figure 1. Permits issued according to employment sectors 1996-2007

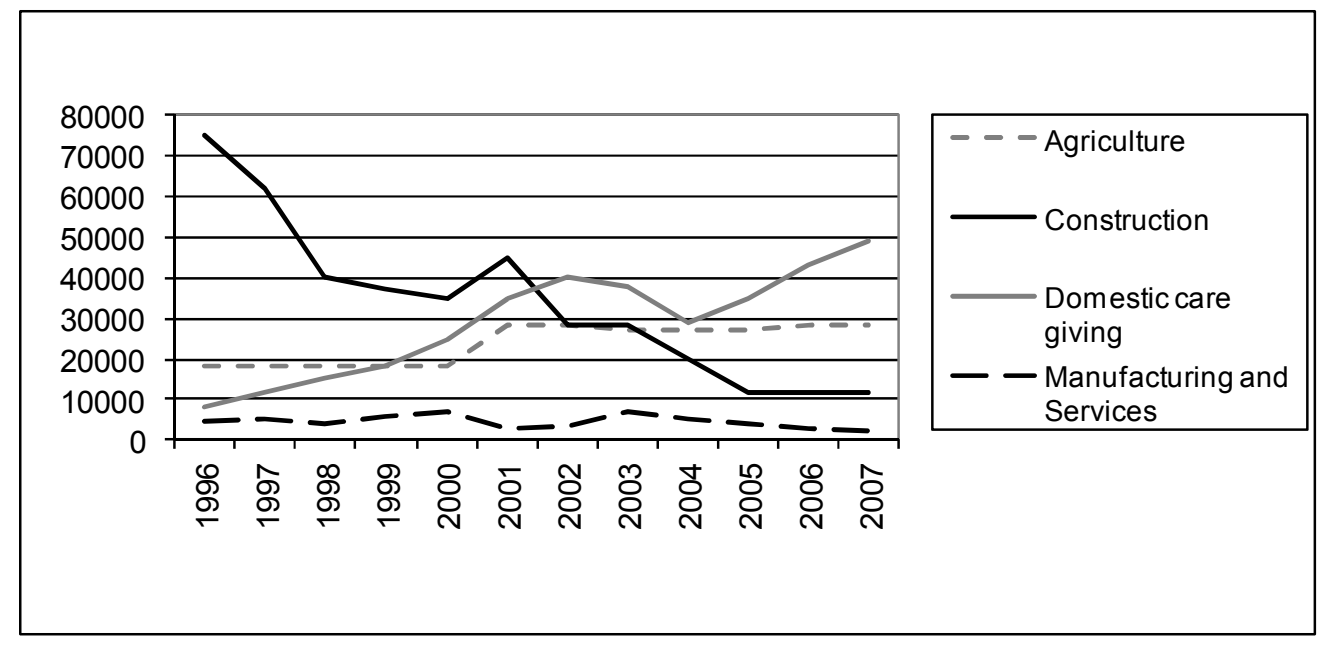

Source: Bank of Israel 2007.

6. As shown in Table 3, the distribution of permits per employment sector in recent years has shifted from construction, the largest employer of foreign workers up until 2001, to agriculture and the elderly care sectors, which are nowadays the main recipient sectors. As part of a policy that at the beginning of 2007 encouraged agricultural export, the government increased the quota allocated to the agriculture sector by 2500 permits. ${ }^{9}$ Elderly care has become the largest and fastest-growing sector employing foreign workers: while in 1996, the sector comprised only $7 \%$ of all permits issued to foreigners, by 2002 the number had quadrupled to $28 \%$ of all permits. ${ }^{10}$ As seen in Table 3, in 2007 more than half of the permits accorded to foreign workers went to the nursing and elderly live-in home-care sector.

7. Since there is a correlation between the employment sector and the country of origin and gender of the foreign worker, the re-distribution of permits per employment sector has led to changes in the ethnic and gender composition of the foreign worker flows (see next section).

8. Unlike the construction and agriculture sectors, where originally foreign workers were meant to replace Palestinian workers from the Occupied Territories, the recruitment of foreign workers in the nursing care sector created ex-nihilo an occupational "niche" of live-in migrant women caregivers, who are managed by private service providers and manpower agencies. The employment of foreign workers, mainly Filipino women, was restricted to private homes, and was aimed at enabling a shift of the geriatric care system from geriatric institutions and hospitals to care in private homes while at the same time saving up to fifty percent of the costs of elderly care. The institutional infrastructure and rationale for employing foreign workers was established with the formulation of the Long-Term Care Insurance Program (LTCIP) in 1986 and its subsequent implementation in 1988. Under the LTCIP, the National Insurance Institute (NII) provides the financing for long-term care services to seriously disabled, chronically ill, elderly people living in the community. The services include non-professional personal care, such as assistance in

\footnotetext{
${ }^{9}$ Government Decision No.1537, 01/04/2007.

${ }^{10}$ The Manpower Planning Authority in the Ministry of Labour and Social Affairs 2003.
} 
dressing, bathing, mobility, feeding, administering of medications and general attendance, as well as help in home-making activities (on the LTCIP see section 3). Clause 8 of the LTCI Bill stipulates that the program provides benefits in kind and that the services are to be provided by non-governmental agencies. According to the Ministry of Finance, which originally pushed for the inclusion of the clause, benefits in kind, and not cash, were to serve as a means of cost containment and allowed the state to develop a market of private-care service suppliers regulated by governmental agencies ${ }^{11}$. Demand for foreign workers, in what was to become the largest employer of foreign labour in years to come, was thus created both by the fact that the LTCIP was from the outset an underfunded social program and by the fact that subsidies were allocated through private for-profit brokers.

\section{Foreign workers with permits: Socio-demographic characteristics}

9. When reporting about authorised foreign workers, the Israeli Central Bureau of Stastistics (ICBS) provides data on the age, sex, country of citizenship and type of employment by year of arrival. Foreign workers with permits in Israel come from approximately 100 countries, though 8 countries account for 93\% of them (See Table 3). Most migrants with permits are young men in their mid-30s (median age 35) who come mainly from Southeast Asia and Eastern Europe. Data show that the ethnic composition of the flows has changed over time, with a decrease in the number of foreign workers from East European countries and Turkey, who worked mainly in the construction sector and were a majority of foreign workers up until 2000. By contrast, the share of foreign workers with permits from Southeast Asia increased from $33 \%$ in 1995 to $48.8 \%$ in $2006^{12}$. Table 3 shows that in 2007 the Philippines, Thailand, and China were the major sources of labour flows to Israel.

10. Alongside the increasing "Asianisation" of labour migration flows into Israel, we are also witnessing a steadily growing trend towards their feminisation. At the end of 2007, women constituted $43 \%$ of all foreign workers with permits in Israel, and $47 \%$ of the entries with a permit during the same year. Their average age was 37.3, slightly above the median age of officially recruited male migrant workers.

Table 3. Foreign workers with permits by main countries of origin/gender (end of 2007, in thousands)

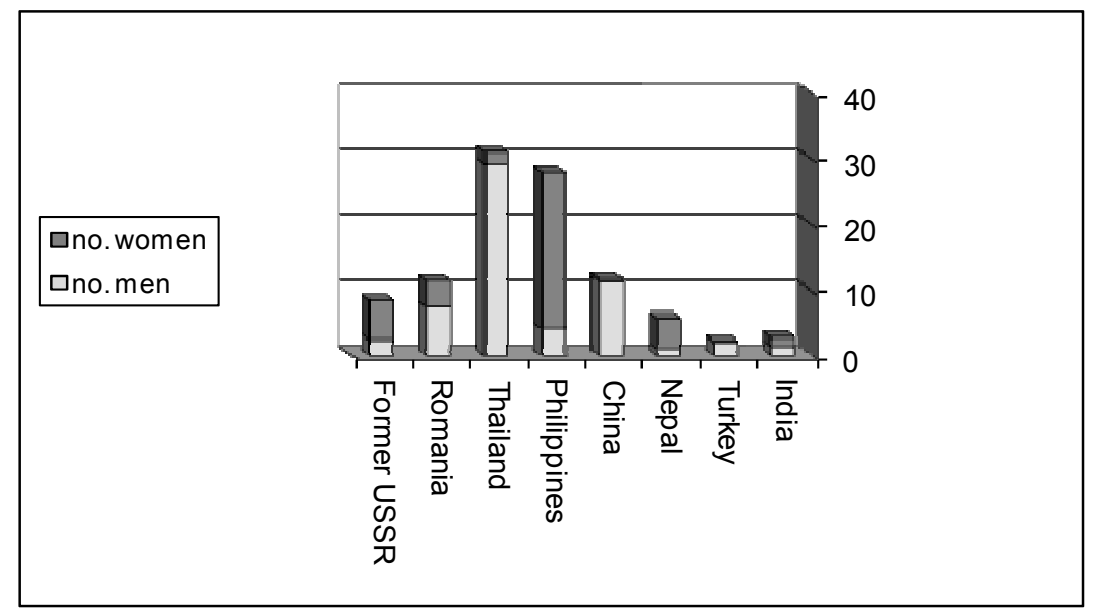

Source: Shaps 2008, Table B.

\footnotetext{
${ }^{11}$ Ofir et al. 2000.

12 ICBS Press Release 30/07/2007.
} 
11. As seen in Figure 1 above, nowadays the major employer of foreign workers is the elderly home care sector, with 49000 permits allocated in October 2007. Given that most of the labour migrants in the elderly care sector are women, the continuation of this trend implies that their proportion in Israel will continue to grow, in keeping with worldwide trends towards the feminisation of migration. Elderly care is also the only sector in which there is no quota limiting the recruitment of foreign workers.

12. The ICBS does not provide detailed socio-demographic information on authorised foreign workers. A more in-depth socio-demographic profile on one particular group, Filipina women, is provided by a survey carried out by the Brookdale Institute in 2002. According to the survey, $96 \%$ of female foreign workers from the Philippines who worked as care-givers in Israel were young women (median age 35) who arrived in Israel for a short-term stay without their families in order to improve their economic situation. $50 \%$ of them were single, and $90 \%$ of the married women reported that their spouse was not in Israel. $48 \%$ of the women had children ( 2 on average), and $92 \%$ of them reported that their children were not in Israel. $66 \%$ reported that their financial situation was "reasonable", while $20 \%$ reported a bad to very bad financial situation. Most women (96\%) reported that they lived in the employers' house and that their work covered a wider range of domestic services besides nursing the elderly. Only $8 \%$ of them had completed an official care-giving training prior to their arrival. $76 \%$ of the women reported that prior to their arrival in Israel they worked in one of the following sectors: $44 \%$ in sales, $16 \%$ in nursing, $8 \%$ in school teaching and $8 \%$ in other profession. Most women reported a weak relationship with the employment agency that hired them ${ }^{13}$.

13. Recent years have seen an increase in the share of women coming from India and Nepal. In 2006, women made up $47 \%$ of the entrants with work permits from India and 83\% of those from Nepal; in 2007 their share grew to $52 \%$ and $87 \%$, respectively. Indian and Nepalese women entering Israel with permits are considerably younger than their Filipino counterparts. Thus, for example, $18.2 \%$ of Nepalese are between the ages of $15-24$, and $35.2 \%$ age $25-29$, in comparison to $5.9 \%$ and $21.9 \%$ among Filipino foreign workers with permits. ${ }^{14}$ However, to date there is not empirically grounded research on the sociodemographic characteristics of these groups and their working conditions in Israel. Given their lack of proficiency in English (or Hebrew), advocacy organisations on migrant worker issues have repeatedly warned of the vulnerable situation of Indian and Nepalese women and reported violations. Apparently, an informal hierarchy has evolved in the home-care sector wherein the most dependent disabled elderly are assigned to migrant worker women from these countries. ${ }^{15}$

\section{Foreign workers without work permits}

The existing information on foreign workers without permits is not very accurate, and should be characterised as estimations. The ICBS estimates that their numbers increased since 2006 and stood at 90000 by the end of 2007 , i.e., $45 \%$ of the total of 200000 foreign workers (Figure 2). ${ }^{16}$

The ICBS bases the estimate on the number of tourists from non-Western or undeveloped countries who enter the country and overstay their visa, assuming that these people end up working without permits as unauthorised foreign workers. Following this assumption, in $2007,74 \%$ of unauthorised foreign workers who entered as tourists came from 10 countries, mainly from the former USSR, Jordan, Mexico, Brazil,

\footnotetext{
${ }^{13}$ Korazim et al. 2002.

${ }^{14}$ Central Bureau of Statistics 2008: Table 4.11 "Entrants with work permits by country of citizenship, age, sex and year of entry."

${ }^{15}$ See Ruth Sinai 2008

${ }^{16}$ It should be mentioned that according to this estimation, the share of the total foreign population made up of foreign workers without permits is today still lower than the levels up until 2002.
} 
and Colombia, countries from which Israel does not conduct official recruitment, and Romania, and Turkey, from which foreign workers are also officially recruited. ${ }^{17}$

Figure 2. Foreign workers without permits 2001-2007

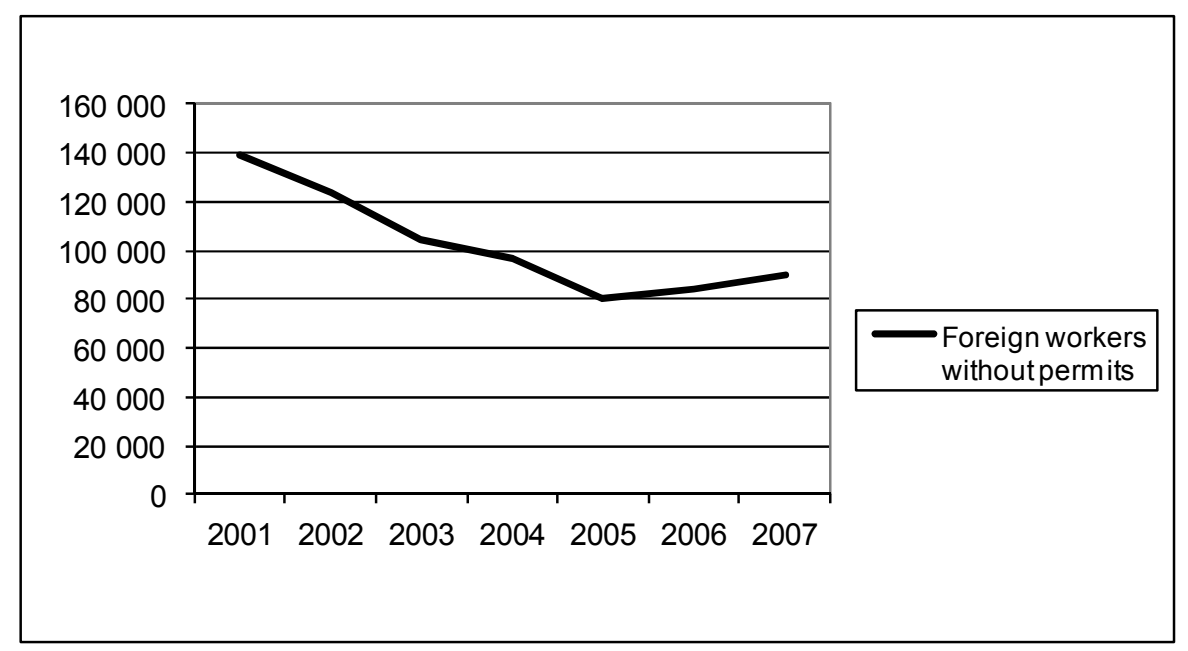

Source: Natan and Tzwebner 2009, Table 1.

14. As shown in Figure 2, the number of foreign workers without permits was at its peak in 2001, it declined until 2005 and increased again in 2006. The decline reflects a deportation policy that became very aggressive upon the creation of the Israeli Immigration police in 2002 (itself a component of the "Closed Skies" policy).

Table 4. Foreign Workers Deported from Israel in 1995-2008

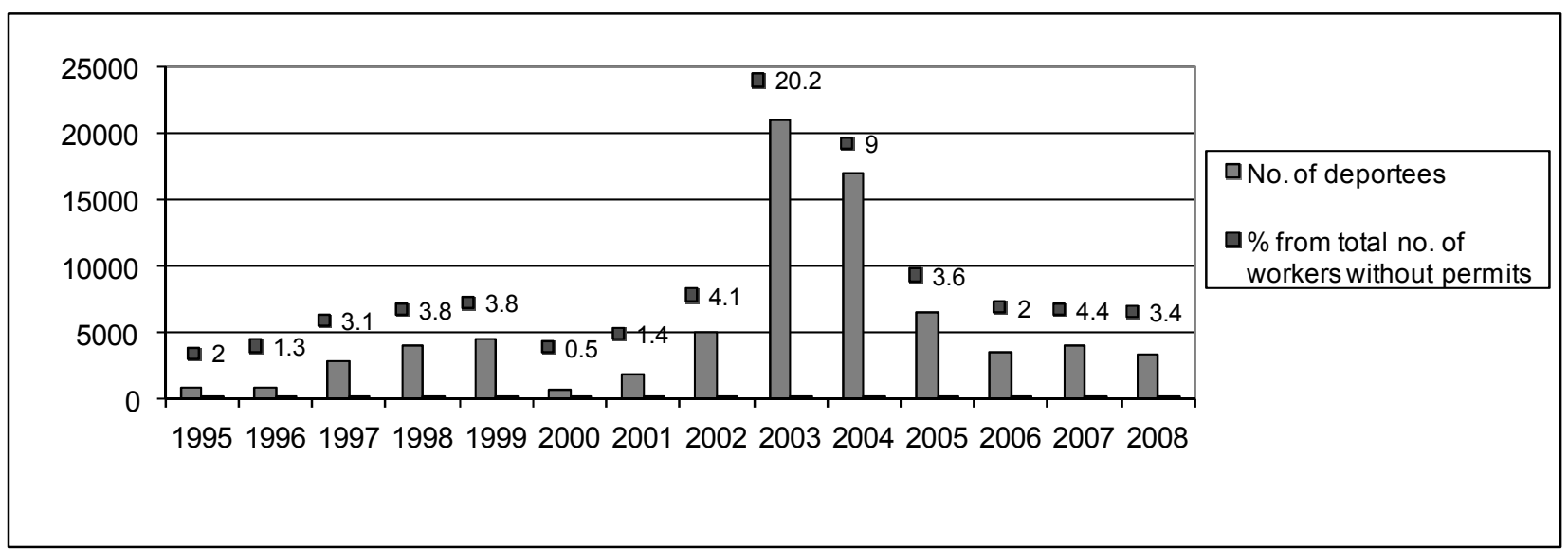

Source: Bar Zuri 2009, p. 15. The percentage of total undocumented is calculated based on estimates from the Interior Ministry.

15. Between 1995 and 2008 approximately 76100 foreign workers without permits were deported. As seen in Table 4, in 2003 the number of deportees comprised $20.2 \%$ of the total estimated population of irregulars. The increase in the number of foreign workers without permits seems to be related to more relaxed police enforcement and to a new policy of re-assignment of workers.

\footnotetext{
${ }^{17}$ Shaps 2008: Table 3.
} 
16. Tourists who overstay their visa are only one type of irregular foreign worker. There are additional modes of becoming a foreign worker without permit; the most pertinent for this report are: first, foreign workers with permits who overstay their work visa: there is no official information about their number; and second, foreign workers who lose their work and residence permits by leaving the employer to whom they are "bound" or attached by contract (known in Israel as a "binding arrangement", see below). According to a survey conducted in the early 2000s, among 4400 foreign workers without permits in prison awaiting deportation, $41 \%$ reported entering the country with a work permit and $59 \%$ with a tourist visa $^{18}$. It is assumed that they were either overstayers or violated the binding system. ${ }^{19}$

17. Foreign workers without permits in Israel work in the same sectors as authorised workers. Thus, for example, at the end of 2006 it was estimated that a significant share of the 23000 foreign workers without permits worked in the construction sector. ${ }^{20}$ Similar estimates are more difficult to make for the elderly care sector. Undocumented foreign workers in significant numbers also work in unauthorised employment sectors such as domestic services, mainly cleaning and child care services and in sectors that get very few permits, such as hosting and catering ${ }^{21}$.

18. The latter sectors have "profited" recently from the unexpected influx of increasing numbers of asylum seekers and refugees from Eritrea and Sudan and their release from detention facilities under limiting conditions. ${ }^{22}$ The integration of asylum seekers and refugees in the hotel industry in the southern city of Eilat has offset to a great extent governmental policies pursued in the labour market since the early 2000s. In 2005, the government established a quota of 550 permits for foreign workers in low-skilled jobs (cleaning, washing dishes, room keepers, etc.) in the hotel industry; all of them were allocated to hotels in Eilat (prior to the quota there were 1500 foreign workers, most of them from African countries, working in Eilat). In April 2006, an agreement was reached between the Hotel Industry Association and the government that would cancel all permits for foreign workers from February 2007 onwards, allowing only for individual permits to be granted under the category of "specialist workers". ${ }^{23}$ Concurrently, an employment program called "Fact" ("Oovda" in Hebrew) was implemented by the National Employment Service (NES) in cooperation with employers in the hotel industry that aimed at integrating Israeli workers into the industry through the creation of various incentives. ${ }^{24}$

\footnotetext{
${ }^{18}$ Bar Zuri 2005.
}

${ }^{19}$ There are two additional ways: people who enter to work in the country with false documents; and people who cross the borders illegally and work without a permit. The latter has been the main route of entry for trafficked women in the sex industry; more recently, crossing the Egyptian-Israeli border has also become the main means of entry for mixed flows of asylum seekers, refugees and economic migrants from African countries (mainly Sudan and Eritrea). To date, there is little to nil information about this new category of immigrants in Israel.

${ }^{20}$ See Eckstein 2007: Table 4, p. 31.

${ }^{21}$ Bar Zuri 2005.

${ }^{22}$ There are no official data on the integration of asylum seekers and refugees in the different sectors of the Israeli labour market. The rather speculative estimation is that 10,000 (out of an estimated total of 20,000) forced migrants are working in agriculture, the hotel and catering industries and domestic services (house cleaning). See Bar Zuri 2009, Table 1, p. 10.

23 A "specialist worker" is a foreign worker who gets paid "double average salary" (NIS 15000 or USD 3 800). Specialist foreign workers are subject to individual authorisation and there is no limiting quota.

${ }^{24}$ The reception of the program has been mixed. Hotels complain that the bulk of the incentives are given to workers already working in the industry and that they are not attracting new ones. Moreover, it has been reported that different sectors within the tourism industry in Eilat are opposed to the idea that large numbers of Israeli-Arab workers, at whom the program was directed, would become long-term residents of the city. See Natan 2007a. 
19. Conversely, in the catering sector, the government is not upholding previous decisions that established the gradual cancellation of quota permits for "ethnic restaurants". In 2009, the quota stands at 900 permits, the same as in $2007^{25}$.

20. A report by the Ministry of Industry, Trade and Labour (ITL) provides the socio-demographic characteristics of foreign workers without permits who were deported in 2007: approximately $80 \%$ were male workers; most of the women who were deported entered Israel with a permit and overstayed their visa as a result of a high demand for female care-givers and domestic workers; $58 \%$ of the foreign workers deported in 2007 were from Asia, 22\% from Africa and 16\% from Eastern Europe; 65\% of the female workers deported were from the former USSR (26\%), the Philippines $(28 \%)$ and China $(11 \%)^{26}$.

\section{Labour migration and its impact on the Israeli labour force}

21. Research led by economists from the CBI found that the large-scale employment of foreign workers in Israel depresses the employment levels and wages of low-skilled Israelis, contributing to rising earnings inequality. Gottlieb (2002) found that the employment of foreign workers, in addition to providing relatively easy access to income support payments, contributed significantly to explaining the exclusion of low-skilled Israeli workers from the labour force and the increasing inequality in gross earnings. Yet the effect of large flows of foreign workers on unemployment is less clear than the effect on the wage structure: the latter can vary, depending on individual occupational and educational characteristics. ${ }^{27}$ The study also showed that the policy of allocating sector-specific migrant permits did not prevent the spill-over of wage-depressing effects throughout other sectors of the economy.

22. Another study that focuses on the construction sector showed that, until several years ago, the increase in the employment of foreign workers was followed by a worsening of wage conditions and unemployment for Israeli workers in the sector, most of them Israeli-Arab citizens ${ }^{28} 29$.

23. Policy makers seem to have taken these findings into account. The decline in the number of foreign construction workers brought about by government policies in recent years ("Closed Skies") led indeed to the employment of a growing number of Israeli-Arab citizens in the sector. According to research conducted at the MITL Research Administration, since 2004 there has been an increase in the number of less- educated Israeli-Arab male citizens who entered the construction sector in "wet jobs", which since 1996 have employed mainly foreign workers. Their re-insertion in the lower tier of the labour market brought about a decrease in unemployment rates among this sector of the population and among lesseducated male citizens in general. ICBS data show that the unemployment rate among low educated Arabs in Israel ( $0-10$ years of education) decreased from $16.8 \%$ in 2002 to $14.1 \%$ in $2004,14.2 \%$ in $2005,14.1 \%$ in $2006,14.8 \%$ in 2007 and $13 \%$ in 2008 . Unemployment rates among Israeli-Arab less-educated male citizens are slightly higher than those among their Jewish less-educated counterparts ${ }^{30}$.

\footnotetext{
${ }^{25}$ Natan 2009a.

${ }^{26}$ Bar Zuri 2008.

${ }^{27}$ The effect of labour migration on the level of employment is perceived as more worrisome by Israeli officials than the effect on the wages of unskilled workers. This is due to the lower participation rates of men in Israel in comparison to Europe and the U.S., which pushes them onto welfare. See Eckstein 2008.

${ }^{28}$ I shall use heretofore the term "Israeli-Arab citizens" to distinguish between Palestinian that are Israeli citizens and Palestinian that are not. The concept does not imply any normative assumption on their subjective identification.

${ }^{29}$ Zusman and Romanov 2003.

${ }^{30}$ Bar Zuri 2009, p. 12.
} 
24. Labour market researchers at MITL Research Administration and economists at the $\mathrm{CBI}^{31}$ attribute the above-mentioned changes mainly to the success of "welfare to workfare" governmental policies in general and to the "Closed Skies" labour migration policy in construction. ${ }^{32}$ Current efforts now concentrate on extending similar policies to other sectors employing foreign workers. According to a recent report submitted by an inter-ministerial committee appointed for the reformulation of labour migration policy, headed by a senior economist from the CBI, the constant increase in the number of foreign workers in agriculture, if continued, will end up replacing Israeli workers and depressing their wage levels ${ }^{33}$. The report also suggested that if the demand for foreign workers in the care-giving sector continues to increase also in institutions for the elderly and disabled people, it will have a negative effect on the employment of Israelis, who work in this sector today ${ }^{34}$.

\section{General description of the foreign workers system}

25. The screening, recruitment, and employment of foreign workers are carried out by private agencies and employers, not by governmental agencies. The Israeli government has not signed bilateral agreements with sending countries.

\section{Role of public employment bodies}

26. Up until 2008, the management of labour migration in Israel was divided among three governmental offices:

1. The Ministry of Industry, Trade and Labour (ITL/ Tamas in Hebrew) and its Department of Foreign Workers, which was in charge of all aspects of the employment of foreign workers;

2. The Ministry of the Interior, which was in charge of workers' entry, stay and departure;

3. The Ministry of Public Security and the Immigration Administration (whose main - if not only - operating unit was the Immigration Police) that has operated within it since August 2002, carrying out legislative enforcement regarding workers' stay without permits and deportations.

27. The National Insurance Institute (NII) plays a key role in the management of the care-giving sector. Under the Long-Term Care Insurance Program (LTCIP) (see section 1), the state subsidises homecare services according to the person's level of functioning and his/her income. ${ }^{35}$ There are two main NII subsidies used to employ foreign workers in homecare: elderly care subsidy and disabled subsidy. As of January 2008, the highest elderly care subsidy stood at NIS 3126 (USD 780) for 18 weekly hours or 168\% entitlement for completely dependent elderly. ${ }^{36}$

\footnotetext{
${ }^{31}$ See Bank of Israel 2007.

${ }^{32}$ This is the idea consistently advanced and advocated in the CBI's annual reports.

${ }^{33}$ Eckstein 2008, p. 81.

${ }^{34}$ Eckstein 2008, p. 104.

${ }^{35}$ Currently, the NII supervises the elderly income level.

${ }^{36}$ Lately some towns conducted a pilot experiment that gives the subsidy to the direct employer (the subsidy entitled elderly) of the foreign worker rather than to the broker agency. The allowance in this case is up to NIS 2501 (USD 620). See National Insurance Institution 2008.
} 
28. The maximum subsidies for disabled people stood at NIS 1937 (USD 490); up to NIS 3450 (USD 860) for special services (150\% entitlement); and NIS 2500 (USD 620) for mobility subsidies. Elderly people who meet the required criteria can receive all subsidies simultaneously ${ }^{37}$.

29. In order to ensure that the money is used for its purpose, the subsidies are transferred directly from the NIS to the manpower agency, and the agency pays the care-giver directly. ${ }^{38}$ For a full-time position, the person hiring the services of the care-giver from the agency needs to cover the rest of the care-givers pay.

30. As of November 2008, 30000 of the 130000 elderly entitled to the LTCI actually employed foreign workers ${ }^{39}$. In September 2008, a reform in the elderly home care sector was partially put in effect. Among others, the reform establishes that the elderly will be the direct employer of the foreign workers, whereas the agencies will provide only intermediation and training services (on the reform see section 7).

31. As of July 2008, with the approval of the Jurisdiction Transfer Bill, procedures and tasks that were previously the responsibility of the ITL, including the coordination of working with private recruitment agencies, have been gradually transferred to the newly established Population, Immigration and Border Passage Authority (PIBPA) within the Ministry of the Interior. In February 2009, the Immigration Administration was transferred to the PIBPA.

32. In addition to governmental agencies, there are municipal and non-governmental organisations that operate in the field of labour migration in Israel. Tel Aviv municipality established the Center for Aid and Information for the Foreign Community (MESILA) in 1999, which provides welfare services for the families and children of the foreign workers, mostly undocumented, especially in the field of education for pre-school children. It also engages in community building and outreach, and carries out preventive work among the high-risk population. The most prominent NGOs advocating on labour migration issues and providing services to foreign workers include: KavLa'Oved (Workers' Hotline); Hotline for Migrant Workers (HMW), Physicians for Human Rights in Israel (PHR), and The Association for Civil Rights in Israel (ACRI).

\section{Quota system}

33. In principle, quotas in each sector are set by the ITL, which also issues employment permits (work permits are issued by the PIBPA) based on the following considerations: In the agriculture sector, employers' demand for workers are taken into consideration and, in principle, employment permits are allocated in accordance with the quota set by the government ${ }^{40}$. In the construction sector, employment

${ }^{37}$ Natan 2008c, p. 2.

${ }^{38}$ There is an ongoing debate about whether the subsidy should be provided as "services" (meaning that the state pays to broker agencies that appoint the care-giver) or through a monthly allowance used to hire the services of the care giver privately. Findings that compare employers' satisfaction with the two types of service show no significant difference (Naon at al. 2004). Therefore, the study recommends considering macro factors, such as the ability of employers (the elderly and their families) to bear the expenses of completely privatised services.

${ }^{39}$ Natan 2008c, 2.

${ }^{40}$ Governmental quotas are more often than not "negotiated" by employers' organisations in court or behind the scenes according to the well-known dynamics of "client politics". Recently, as a result of a legal appeal by the Farmers' Association, a large number of permits were approved in addition to the original quota. Following a 2008 governmental decision, 2,500 permits were also issued for farmers who specialise in exporting produce. According to governmental decision, additional permits would be given provided that exporters employ one Israeli worker per each additional permit allocated for foreign workers (Israel Government 2007). This provision was however not enforced (Phone Interview with Anat Kidron, KavLa'Oved, March 2009). For more on this issue 
permits are allocated according to the quota and are divided evenly among listed, authorised corporations that serve as the employers. According to the Endorn Committee that established the new employment principles in the construction sector (see below), each licensed manpower corporation is to be allocated a definite number of permits that oscillates between 500 and 2000 permits. ${ }^{41}$ As for the allocation of foreign workers to contractors, the only condition is that they have to be registered in the Constructors Register as licensed constructors. ${ }^{42}$

34. The contractors hire the workers' services from the corporations. In all other sectors, including that of domestic elderly care, employment permits are allocated to employers by the ITL. There are no predetermined quotas for home care for the elderly and disabled, and the Israeli NII carries out entitlement tests for nursing patients who are potential employers ${ }^{43}$.

35. After the allocation of employment permits to employers according to the quotas in each sector, recruitment agencies in Israel contact agencies in sending countries, which recruit suitable workers. When suitable workers are found abroad, their details are transferred to the Ministry of the Interior, which is in charge of foreign workers' admission into the country, under the Israeli Entry Law (1952). ${ }^{44}$

\section{Pre-screening and exclusionary criteria}

36. In order for a worker to receive a work permit from the Ministry of the Interior, several conditions must be met $^{45}$ : the worker must not have worked in Israel for a period longer than 4 years, nor have relatives in Israel, ${ }^{46}$ nor be older than 60 nor have a criminal record or health problems. If the worker meets these conditions, the Ministry of the Interior gives permission to the Israeli Consulate in the sending country to grant him/her a work permit in Israel ${ }^{47}$. While foreign workers in agriculture and construction who apply for a work permit do not need to attend the Israeli Consulates in person as part of the screening process, domestic care-givers attend a personal interview and must pass a language (English) and a professional qualifications test.

37. Until February 2009, no guidelines on how to perform the tests and conduct the pre-screening interview had been published. Therefore only criminal records and the health situation of the worker were checked. Women that apply for work in Israel undergo pregnancy texts ${ }^{48}$. The fact that no interviews were held until recently, except for home care workers, and the absence of published guidelines for the interview, hollowed out the whole meaning of the screening process and left the prospective foreign workers completely ignorant about the conditions for the visa, and their rights and duties. Organisations such as the HMW and Kav La'Oved argued time and again that the screening process carried out by private agencies at the Israeli consulates in the sending countries displayed two major flaws: workers are recruited despite a lack of the minimum required level of language proficiency in English, and they are

see Knesset Committee for the Examination of the Problem of Foreign Workers (heretofore: Committee on Foreign Workers) 2009, p. 14.

${ }^{41}$ Interministerial Committee 2004.

${ }^{42}$ E-mail communication with Hanna Zohar, Workers Hotline, May 25, 2009.

${ }^{43}$ Eckstein 2007, 38.

${ }^{44}$ Immigration Administration 2005.

${ }^{45}$ For PIBPA regulations, see: Ministry of Interior 2009.

${ }^{46}$ See Section 5 on Procedure on Pregnant Foreign Workers, p. 21.

${ }^{47}$ Eckstein 2007, p. 38.

${ }^{48}$ Natan 2009. 
given inaccurate information in regard to their rights and duties in Israel. All of the above leads to the exploitation of workers after they arrive to Israel, and to their unemployment and loss of work permits. ${ }^{49}$

38. Following these allegations, in February 2009 the Ministry of the Interior submitted to the Israeli Ministry of External Affairs written guidelines for interviewing prospective long-term care (LTC) foreign workers in Israeli consulates in the countries of recruitment. The new guidelines require language proficiency in English only from LTC workers.

39. According to a report submitted by the Knesset Research Institute, however, considerable pressure is exerted on Israeli consular officials to accept candidates for work in Israel even when they are not found eligible. The report does not provide details as to exactly who is exerting pressure ${ }^{50}$. Nevertheless, the report concludes that as long as the work permits are given to brokers and allocated through them, the pre-screening process will not be based on objective criteria (such as whether the workers' skills are fit for the job, his/her ability to communicate with the employer, health conditions, and others) but on private interests driven by profit seeking ${ }^{51}$. As will be seen in the concluding chapter on recommendations, I fully concur with this view. As long as the recruitment process is not insulated from private brokers' and other stakeholders' profit-seeking pressures, screening will not rely on objective criteria. Israeli embassies and consulates in the countries where foreign worker recruitment is conducted can and should play a central role in monitoring the screening and recruitment process and in ensuring that it conforms to established guidelines, and more importantly, they can play an important role in pre-empting the collection of illegal fees by intermediary agencies by helping to identify and denounce criminals. Moreover, it is important to provide clear information and documentation in a language that is understandable to workers, as well as autonomous interpreters. While this may not be sufficient to prevent the violation of foreign workers' rights, it should be a necessary and obligatory requirement at all stages: the screening stage, later while inspecting the working conditions, and when and if detained and arrested. Preference should be given to foreign workers in the construction and agriculture sectors who are proficient in English, though I am aware that this may not be attainable.

\section{Recruitment fees}

40. Maximum recruitment fees that may be legally charged foreign workers recruited abroad should not exceed NIS 3276 (USD 730), including fees paid to agents abroad and to the Israeli agency, but not including the air fare. According to Israeli law, it is also illegal for anyone to collect recruitment fees from foreign workers for a new placement once the worker is already in the country. Yet the collection of illegal recruitment fees that is fuelling a full-fledged industry to import and exploit foreign workers has been a focus of NGO campaigns and semi-official denunciations ${ }^{52}$, as well as media coverage, for much of the last decade and a half. ${ }^{53}$

\footnotetext{
${ }^{49}$ See Knesset Committee for the Examination of the Problem of Foreign Workers 2009a.

${ }^{50}$ Natan 2009 b, p. 3.

${ }^{51}$ Natan 2009b, p. 5.

${ }^{52}$ For semi-official denunciation of this phenomenon, see Hagai Herzl, advisor to the Ministry of Internal Security, in Knesset Committee for the Examination of the Problem of Foreign Workers 2002; Schlomo Benizri, Minister of Labour at the time, referred explicitly to the deceit at a session of the Knesset Committee for the Examination of the Problem of Foreign Workers 2002a.

${ }^{53}$ The case of 13000 Chinese foreign workers recruited in return for high fees who, once in Israel, were "dumped" in the airport without work called public attention to the phenomenon in December 2001. See Meiri, Oron, Meiron Rapoport and Ofer Petersburg 2001; for more on the media exposure of the labour migrant trafficking industry, see the television program Chasifa [Exposure], Israeli TV, Channel 1, 27 Feb. 2002.
} 
41. Several reports published on the recruitment process show that foreign workers are subject to exploitation by private recruitment agencies, both abroad and in Israel $^{54}$. Private recruitment agencies abroad charge high and illegal fees from workers, ranging from USD 5000 in average paid by domestic care-givers from the Philippines ${ }^{55}$ up to USD 25000 from Chinese construction workers ${ }^{56}$. Though there are no precise figures regarding the amount of money that is transferred to recruitment agencies in Israel, in the case of Chinese construction workers, it has been estimated that up to $70 \%$ of this is transferred back to Israel ${ }^{57}$. Due to the high fees involved, it is calculated that, in average, domestic care-givers from the Philippines need to work in Israel for 9 months and Chinese construction workers for 2 years in order to cover the loans that they have to take out back home to pay the high recruitment fees.

42. The economic incentives to import foreign workers and the lack of effective supervision and enforcement by the authorities created a situation whereby agencies would request more work permits than were actually needed. Then they would trade in work permits, creating a "workers' bank" for a constant supply of foreign labour or conversely, a pool of unemployed foreign workers who were deportable and therefore, also replaceable. ${ }^{58}$ Media coverage through the years disclosed suspicions about the direct involvement of officials in the agencies responsible for allocating the permits. ${ }^{59}$

43. In response to the deficiencies found in the recruitment process, in July 2005 the government introduced a new method, which would include the signature of bilateral agreements with sending countries and using the services of the International Organization for Migration (IOM) in the recruitment process. ${ }^{60}$ For recent changes and developments in policy regarding the recruitment process, see Section 7.

\section{Policy issues: The Binding Policy and Human Trafficking}

44. Until 2005, the foreign workers system was based on the "binding policy", which makes the work visa of foreign workers valid only for a single employer. As a result of any change in work relations, such as dismissal, resignation, or employer bankruptcy, foreign workers lost their residence permit and became subject to arrest and deportation.

45. Under the binding arrangement, foreign workers are prone to severe violation of their rights ${ }^{61}$. Any foreign worker who demands that the employer respects labour legislation on working conditions or seeks remedies for such violations faces the risk of being immediately fired and losing their legal status. Moreover, employers can "sublet" the services of "their" workers to other employers, without the workers' consent. In addition, losing the work permit as a result of the binding policy would have negative consequences on the worker's ability to repay the loans they have taken out back home to pay the high and

\footnotetext{
${ }^{54}$ Eckstein 2007, p. 39; Natan 2008b; Horen 2008; Shaked 2008.

${ }^{55}$ Horen 2008.

${ }^{56}$ Shaked 2008.

${ }^{57}$ Shaked 2008.

${ }^{58}$ How did this "workers' bank" operate? Representatives of the manpower agencies approached employers who were permitted to bring workers to Israel and undertook to supply them, provided they applied for more than they actually needed (preferably labourers from China, as they were the most profitable). The companies also offered the employers cash (USD 1 200) or "presents" for each worker they imported through them. For a full description see Meiri, Rapoport and Petersburg 2001.

${ }^{59}$ On suspicions regarding the involvement of Employment Service representatives in trafficking in labour migrants, see Gilat, Mordechai, and Michal Grayevski 2000; Sinai 2001; Sinai 2001a.

${ }^{60}$ See Government Decision No. 4024, 31/07/2005. See also Physicians for Human Rights 2006.

${ }^{61}$ Berman 2007; Eckstein 2007; Shaked 2008; PHR 2006; Tabibian 2004.
} 
illegal recruitment fees abroad. All of the above encourages widespread exploitation and human trafficking, as stated in the report made by the Hotline for Migrant Workers (HMW) ${ }^{62}$. On 30 March 2006, after six human rights organisations appealed to the High Court of Justice, the Court repealed the binding policy and ordered the government to devise a new employment system by October 2006.

\section{The Endorn Report and the new employment arrangement in the construction sector}

46. In 2004 an inter-ministerial committee released the Endorn Report, which submitted recommendations for replacing the binding employment method in the construction sector by a new method. ${ }^{63}$ In May 2005, a new method that involved issuing employment permits to licensed employment agencies, or corporations, rather than to single employers came into effect. ${ }^{64}$ Under the new system, contractors hire the services of workers from 43 licensed employment agencies, which serve as the employers. Employees are allowed to change corporations once every 4 months, and have 30 days to find a new corporation to hire them. The corporations need to deposit high fees for each worker in order to achieve two goals: ensure the workers' rights, and increase the costs of hiring foreign workers in order to reduce their desirability in the sector (and replace them by Israeli workers, mainly Israeli-Arab citizens). The annual fees paid for each worker in the construction sector come to NIS 4430 (circa USD 1 100) along with an annual license fee of NIS 10743 (circa USD 2 700). ${ }^{65}$

47. Fees also serve as an incentive to ensure that workers leave on time or even before time. First, corporations make a deposit in addition to the worker's wages (i.e., minimum wage) and the abovementioned fees, which can be redeemed once the worker leaves. This creates a certain incentive for the worker to leave. The system in the construction sector even creates an incentive for corporations to have their workers leave before time. Corporations can be retroactively refunded for the period in which the worker has not been employed during the fiscal year and get back part of the annual fees paid. This can give corporations an incentive to have workers deported in order to get a refund ${ }^{66}$.

48. The corporations are required to inform the workers about their rights and entitlements. The new method is designed to protect workers from exploitation and criminal employers and to reduce the administrative work involved in supervising a large number of contractors.

49. In practice, the evaluations of the effectiveness of the new arrangement are mixed. Some evaluations indicate that the new method improves the supervision of employment conditions and thus improves their situation. Others point out that the workers are still "bound" to the corporations and still exploited by employers. Although the new system led to a rise in foreign construction workers' wages, as intended, workers are now also paying higher fees and commissions to work in Israel. In addition, deposits are not confiscated from corporations that violate workers' rights ${ }^{67} .{ }^{68}$ For more information on the proposed employment arrangement in the care-giving and agriculture sectors, see section 7.

\footnotetext{
${ }^{62}$ Berman 2007.

${ }^{63}$ See Interministerial Committee 2004.

${ }^{64}$ A revised procedure came into force on January 2007; see Berman 2007, pp. 16.

${ }^{65}$ For more information, see Ministry of Industry, Trade and Labour 2008.

${ }^{66}$ Ibid.

${ }^{67}$ Eckstein 2007; Berman 2007; Natan 2007b; Shaked 2008.

${ }^{68}$ See the case of the Binyian Mair (Fast Building) Corporation, whose permit was revoked after it was found guilty of unpaid salaries and false reports on FWs leaving, and yet no bonds were forfeited. On the letter announcing the loss of its permit, see
} 


\section{Human Trafficking}

50. The combination of recruitment fees, the binding system and deportations was critical in giving rise to human trafficking for the purposes of labour. At the end of 2006, the Law against Human Trafficking came into force ${ }^{69}$. For the first time, the Law considers trafficking in persons for the purpose of labour and other purposes as a criminal offence (in addition to legislation against trafficking in women). In the U.S. State Department's 2007 annual Trafficking in Persons Report (TIP), which was published in June, Israel was placed in the Tier 2 category of countries that have made efforts to combat trafficking in human beings, but have yet to fully comply with the minimum requirements. A study by the HMW showed that the authorities, such as the Immigration Administration (Police), lack the knowledge and skills needed to identify trafficking offences. It also showed that instructions with regard to the enforcement of the new Law are not clear or explicit. ${ }^{70}$

\section{General employment conditions and access to social benefits}

51. Under Israeli law, a foreign worker in Israel is entitled to the same working conditions as an Israeli employee. ${ }^{71}$ In addition, employers must give workers a written employment contract and provide private health insurance and proper housing. The following is an abridged account of the general employment conditions and rights that apply to foreign workers as they appear on the ITL's Foreign Workers' Rights Handbook:

1. Legal Employment: Only employers who hold a valid employment permit can employ foreign workers, who may only be employed with a work permit (B/1). Foreign workers can leave or change their employer but must notify the ITL. ${ }^{72}$ The length of work permit issued to foreign workers by the Ministry of the Interior is limited to the period set out in the employers' employment permit, or to a period of 1 year, whichever is shorter.

2. Withholding of Passport: Holding a worker's passport against their will is illegal.

3. Health ${ }^{73}$ : Employers are obligated to provide foreign workers with private medical insurance for non-work-related injuries throughout the employment period (whether or not they have a permit). In addition, any person needing emergency medical care will receive it in Israeli hospitals, but will be billed for it if they lack medical insurance.

4. Social Security: The Israeli National Insurance Institute provides foreign workers with insurance in case of work injuries or motherhood. In addition, it reimburses foreign workers whose salaries are unpaid.

5. Housing: Employers must provide their employees with appropriate housing ${ }^{74}$ throughout the employment period and for at least a week after it ends.

http://mail.google.com/mail/?ui=2\&ik=bf3c7a8a06\&view $=a t t \& t h=12196 c 8405 c 8 f c 8 d \& a t t i d=0.2 \& d i s p=a t t d \& z w$

${ }^{69}$ The Law of Forbidding Trade in Humans, 2006.

${ }^{70}$ See Levenkron, Naomi 2007.

${ }^{71}$ For more information see Ministry of Industry, Trade and Labour 2009.

${ }^{72}$ With the exception of the construction sector, where employees can change employers/corporations only quarterly (unless their rights have been violated).

${ }^{73}$ See also in Physicians for Human Rights 2007.

${ }^{74}$ As stipulated in the Handbook cited above (Ministry of Industry, Trade and Labour 2009, p. 2). 
6. Written Employment Contract: Employers must give workers their employment contract in a language they understand.

7. Salary and its Components: Workers are entitled to a minimum wage of NIS 3850 (20.70 per hour with a maximum of 186 hours per month). In addition, workers are entitled to pay for overtime work hours, a travel allowance, and "recuperation pay" once a year.

8. Deductions from Salary: Employers may deduct sums from a foreign worker's wage only for payments required by law: income tax and national insurance; housing ${ }^{75}$; private medical insurance ${ }^{76}$; and debts owed by the employee.

9. Weekly Rest Day and Leave: Under the Work Hours and Rest Law (1951), workers are entitled to a weekly rest period of at least 36 hours. The rest period must include Friday, Saturday or Sunday, depending on the worker's religion. In addition, workers are entitled to paid vacation for a certain number of days each year, as well as for religious holidays and for sickness. ${ }^{77}$

10. Ending Work Relations: Workers employed on a monthly basis must give prior notice of termination to their employer. ${ }^{78}$ In addition, an employee who is dismissed after one year or more of employment is entitled to severance pay.

11. Filing Complaints: Employers who violate the above obligations commit an administrative offence and can be fined for up to NIS 5000 (USD 1 250) for each violation. In serious cases criminal charges will be filed against such employers. Workers whose employer does not follow the above obligations can file a complaint with the Branch for the Enforcement of Labour Laws of the MITL. ${ }^{79}$

12. Recruitment Agencies: The maximum recruitment fee that may be legally charged from foreign workers recruited abroad, in addition to air fare to Israel, is NIS 3 276. It is illegal for anyone to collect recruitment fees from foreign workers for a new placement once in the country.

13. Sexual Harassment: An employer or other person who sexually harasses an employee is committing a sexual offence.

52. More rights of foreign workers as published by the NGOs that operate in the field of labour migration in Israel $^{80}$ :

${ }^{75}$ Limits for sums deducted for housing are set out in the regulations, see p. 4 in the Foreign Workers Rights Handbook (Ministry of Industry, Trade and Labour 2009).

${ }^{76}$ Limits for sums deducted for private health insurance are set out in the regulations, see p. 4 in the Handbook (Ministry of Industry, Trade and Labour 2009).

${ }^{77}$ For more details on the exact number of days of paid vacation/sickness see p. 4 in the Handbook (Ministry of Industry, Trade and Labour 2009).

${ }^{78}$ For more details on prior notice, see p. 5 in the Foreign Workers Rights Handbook.

${ }^{79}$ Recently, it was suggested that the enforcement of foreign workers' rights should be transferred to the new PIBPA as well.

${ }^{80}$ Kav La'Oved http://www.kavlaoved.org.ill, Hotline for Migrant Workers http://www.hotline.org.il/, Physicians for Human Rights http://www.phr.org.il/phr/ 


\section{Attempts to exclude foreign workers from their labour rights under the law}

1. Work Hours and Rest Law (1951): In November 2008, the Israeli Labour Court ruled that the Work Hours and Rest Law (1951) does not apply to a worker in the home care sector, who will not be entitled to pay for working more than 8 hours. The court justified the decision with the argument that home care work has specific characteristics that categorise it as a "trust-job", meaning that it cannot be defined by regular work hours. Kav La'Oved and other advocacy NGOs objected to the attempt to exclude home care workers from the Law and filed an appeal with the High Court of Justice. ${ }^{81}$ Employer representatives (e.g., Disabled People Association, the Disabled Struggle Committee and the Association for Disabled People Now, among others) opposed the appeal, arguing that the people they represent (elderly and disabled) have limited resources and depend on government allowances and therefore cannot pay their care-givers for overtime. ${ }^{82}$ Meanwhile, another ruling by the Israeli Labour Court on the same issue established that the Work Hours and Rest Law does apply to foreign workers in the home care sector. ${ }^{83}$

2. Women Labour Law (1954) and Equal opportunity in employment (1988): both laws sanction the release of women from work on the grounds of pregnancy or childbirth, and establish that it is illegal to fire a pregnant worker who has worked at least six months for the same employer. ${ }^{84}$ In principle, when a foreign worker gives birth, she should get coverage for the hospital stay as well as a one-time birth payment (maternity grant). Workers with a permit are also entitled to 14 weeks of paid maternity leave from National Insurance. However, according to the "Pregnant Foreign Worker Procedure", the foreign worker is requested to leave the country no later than three months after the date of birth, otherwise she loses her legal status. ${ }^{85}$ In November 2005, five human rights organisations appealed to the High Court of Justice (HCJ) against this procedure, which according to the Equal Employment Opportunity Law discriminates between the labour rights of Israeli women and foreign women. ${ }^{86}$ The appeal is still pending.

3. Manpower Agencies Law (1996): In November 2008, the Knesset passed a first call for a bill that will exclude foreign workers from the protection of this law, which seeks to protect workers from the ravages of flexibilisation upon completing 9 months of employment. ${ }^{87}$ Excluding foreign workers from the law would mean that under the law they would be continuously employed by, and therefore bound to, the manpower agency, and not by the actual employer. Under these conditions, foreign workers will be entitled to fewer rights than Israeli workers.

4. Family Reunification ${ }^{88}$ : Israel does not allow family reunification for foreign workers staying lengthy periods of time. Further, having a first-degree relative in Israel is grounds for permit loss and deportability (see above on the "Pregnant Foreign Worker Procedure"). Israeli Law does, however, protect the right of a person to have a family and conduct a family life. Yet

\footnotetext{
${ }^{81}$ See Kav La'Oved website: Zohar, Hanna 2008 and Zohar 2008a.

${ }^{82}$ See Knesset Committee for the Examination of the Problem of Foreign Workers 2008.

${ }^{83}$ Serafima Bodeic v. Doni Hana

${ }^{84}$ See Kav LaOved v. the Ministry of the Interior.

${ }^{85}$ For more information, see Ministry of Interior 2009a. The procedure is grounded on prohibiting foreign workers to have a first-degree relative in Israel; see Section on Pre-screening and exclusionary criteria, p. 12.

${ }^{86}$ Livnat, Yuval 2008.

${ }^{87}$ See the bill at Israel Government 2008.

${ }^{88}$ See Michaeli, Reut 2008 and information on the New Family Organisation website: http://www.newfamily.org.il/
} 
the extent to which that right has to be realised within Israel is under debate in the Israeli HCJ. Israelis who want to marry foreigners need to address the Ministry of the Interior regarding the legal status of their foreign spouse. In order to receive legal status, the couple must meet the following criteria: (a) "[If] the relation is honest and genuine" (b) "[If] the life center of the couple is in Israel". The application procedure takes approximately 5 years, during which the foreign spouse gradually receives a work permit (B1) and temporary residency (A5), and, 4 months after receiving the A5 visa, the foreign spouse is entitled to National Health Insurance services and all the social benefits that Israelis are entitled to. If the couple manages to complete this procedure, the foreign spouse can apply for citizenship.

With regard to marriage, the option of civil marriage does not exist in Israel, and it is possible to get married inside the country only if the spouses have the same religion. If not, the Israeli government recognises any marriage certificate that is recognised by the country in which the marriage took place. If the couple cannot go abroad or does not want to marry, Israel recognises Common Law Marriage ("Yeduim Batsibur" in Hebrew). Although the demands of the Ministry of the Interior are the same, this procedure is longer than the one described above, and more difficult. In addition, a foreign spouse has fewer rights under a Common Law Marriage. For example, the state claims that he/she will not be able to bring in their children with a previous spouse or their parents. Recently, the Ministry of the Interior has been taking a harder line in dealing with the applications of Common Law couples ${ }^{89}$.

All these procedures refer to undocumented residents as well. However, if a foreign spouse was arrested before applying to the Ministry of the Interior, his/her request will be denied and he/she will have to leave the country and would be able to return only upon the request of the Israeli spouse, but this will be more difficult. If for some reason the couple do not complete the procedure, the foreign spouse is asked to leave Israel (with a few exceptions ${ }^{90}$ ).

In 2006, a bill was proposed concerning "Illegal residents in Israel." ${ }^{11}$ According to the proposed bill, any person who stays in Israel without a legal permit and who wishes to apply for legal status will have to leave the country for at least 1-5 years before doing so. This Law would make family reunification with non-citizens, including foreign workers, almost impossible. In principle, the bill, if approved, will affect only those foreign workers (and non-citizens) who reside illegally in Israel. However, in practice, since 1996 the Ministry of the Interior has been applying internal regulations that make it extremely difficult for non-Jews to apply for legal status on the grounds of marriage (see the "Family Reunification" section above).

\section{Violations and Enforcement of rights}

53. So far, the Unit for the Enforcement of Labour Laws at the ITL Ministry has been in charge of enforcing the above-mentioned regulations and sanctions on employers. The ITL is also authorised to charge financial penalties from employers and press charges against them. In 2006, the ITL opened approximately 4000 investigatory files on employers. In addition, 5000 cases were still in the process of filing indictments against employers and 8000 financial penalties were assessed, for a total of

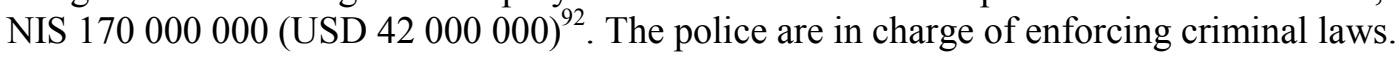

\footnotetext{
${ }^{89}$ For more information, see Laissez Passer 2009.

${ }^{90}$ For more information, see Michaeli, Reut 2008.

${ }^{91}$ See Israel Government 2006.

${ }^{92}$ Eckstein 2007.
} 
54. However, several reports indicate that there are deficiencies in the ITL's enforcement procedures. Reports from Kav La'Oved show that only a small portion of the hundreds of complaints filed were actually processed ${ }^{93}$. Moreover, even though the cancellation of employers' employment permits is the most effective sanction for the violation of rights, it is still rarely used by the ITL especially in the homecare sector ${ }^{94} .^{95}$ Other enforcement means, such as filing indictments against employers or financial penalties, are also not used sufficiently ${ }^{96}$.

55. A report released by Kav La'Oved in 2008 on the situation of Chinese construction workers noted that under the new corporate arrangement, $70 \%$ of corporations violated the rights of workers. The most common violation was delayed wages (64\% of complaints filed in 2008). Before the new arrangement, employers would delay payment of monthly wages. Since the new arrangement came into force, corporations found a way to bypass the regulations and delay wages for the last month of work in each quarter. Other common violations are not complying with social rights $(17 \%)$ and a lack of proper treatment of permit issues $(17 \%)$. There has been a decline in the number of complaints about withholding passports, the lack of medical insurance and illegal deductions (with each at approximately 4\%). Kav La'Oved also reports a phenomenon of Chinese "sub-agents" who serve as middlemen between the workers and employers, and who use criminal means to cover violations of rights, such as extortion and severe violence. The organisation reports that there have been improvements in cooperation between them and the Immigration Administration with regard to complaints and the investigation of such offences ${ }^{97}$.

56. The fraud reported most commonly takes place in the care-giving sector, and is called the "Flying Visa": foreign workers pay high, illegal recruitment fees in their home country, but upon arrival find that no employer is waiting for them and that their work permit is not valid. After losing their legal status, foreign workers who have been victims of this "Flying Visa" not only fail to find work but also are unable to return home since they cannot repay the loans they took out for the high recruitment fees. According to Kav La'Oved, in 2007 there were 10000 foreign workers in Israel who arrived with a permit to work in the care-giving sector but did not find an employer and, having no other choice, worked in other kinds of jobs without a permit. The organisation reported that the Immigration Administration has not dealt adequately with the phenomenon and that the Ministry of the Interior prefers to put the blame on the workers themselves. Another common violation is salaries that fall below the minimum wage. Kav La'Oved reports that the average monthly wage of a foreign worker in the care-giving sector was NIS 2200 (for 6 days of work), which is NIS 1200 less than the minimum wage, with no payment for overtime $^{98}$. The maximum workweek that applies in the homecare sector is 186 hours. NGOs are demanding differential wages for homecare foreign workers, in accordance with the health situation of the employer/patient and the difficulty of the work involved (up to 220 weekly hours). ${ }^{99}$ According differential wages based on NII subsidies should be in the interest of all the stakeholders: government officials interested in "closing the skies" and introducing permit caps in the home-care sector too; employers/patients who are highly dependent on intensive day-long home care and need to "compete" with less-demanding and less needy patients; and foreign workers who can base their choice of employer on utility-driven considerations.

\footnotetext{
${ }^{93}$ Shaked 2008, p. 12.

${ }^{94}$ Natan 2008c, p. 6.

95 The reform in the home-care sector established a bond of NIS 500000 , to be forfeited in case of a violation of foreign workers' rights, yet it does not establish a clear mechanism for doing so.

${ }^{96}$ Socio and Shaked 2008.

97 Shaked 2008.

${ }^{98}$ Safran 2008.

${ }^{99}$ E-mail communication with Hanna Zohar, Workers Hotline, 25 May 2009.
} 
57. According to Kav La'Oved ${ }^{100}$, foreign workers in the agriculture sector are especially vulnerable to violations of their rights, because they often reside in remote areas and are thus relatively isolated, do not speak English and are still bound to their employer. Findings published by the organisation indicate that often these circumstances lead to severe violations of the rights of foreign workers in agriculture. Most of the reported complaints are about delayed wages. Thai workers pay high recruitment fees of USD 7 000USD 8000 prior to arrival.

58. In addition, it was reported that private agencies in all sectors in Israel ask employers to falsely report that they need more workers. The agencies can then charge recruitment fees from more foreign workers and leave a share to the employers (approximately USD 1000 per worker). The foreign workers recruited in this way have no jobs once they arrive in Israel and often lose their permit as a result of the binding policy. According to a report by the Knesset Research and Information Center, foreign workers in the agriculture sector suffer the most severe violations. The average real wage paid to foreign workers in this sector is NIS 100 for an 8-hour day and NIS 14 for every extra hour. As a result, in order to attain the minimum wage, these workers have to work 7 days a week for a whole month ${ }^{101}{ }^{102}$

59. A publication by Kav La'Oved ${ }^{103}$ reports on 97 complaints of various criminal offences filed by foreign workers in 2008, including: withholding of passports, false commitments to arrange a work permit in return for money, human trafficking, sexual harassment and assaults. All the complaints were related to the weak position of foreign workers and to the binding policy.

60. Recently, it was suggested that under the "Transfer of Responsibility" bill the enforcement of foreign workers' rights should be transferred to the new PIBPA as well. The intention is to improve the enforcement of foreign workers' rights by keeping the management of foreign labour in Israel under a single authority. However, the former ITL Minister, Eli Yishai, suggested excluding foreign workers in the care-giving sector from the new arrangement, based on the intention to provide better protection for employers as well. Several NGOs had already requested postponing the discussion before the bill stands for the second vote.

\section{Inspection regime, deportation policy for irregulars and regularisation (amnesty) procedures}

\section{Foreign Workers in Detention and Deportation Policy ${ }^{104}$}

61. According to the Israeli Entry Law (1952), a policeman or inspector who is authorised by the Minister of Interior can arrest a foreign citizen suspected of an illegal stay. The foreign worker does, however, have rights during the arrest, detention and deportation process. ${ }^{105}$

62. It is illegal for the police to burst into someone's home without a warrant or to use violence. The detained person must be brought before a Ministry of the Interior border inspection supervisor within 24 hours. The supervisor can decide to release the person with or without bail if he/she is convinced the detained person is in Israel legally or has lost their permit innocently. If held in detention, the detained

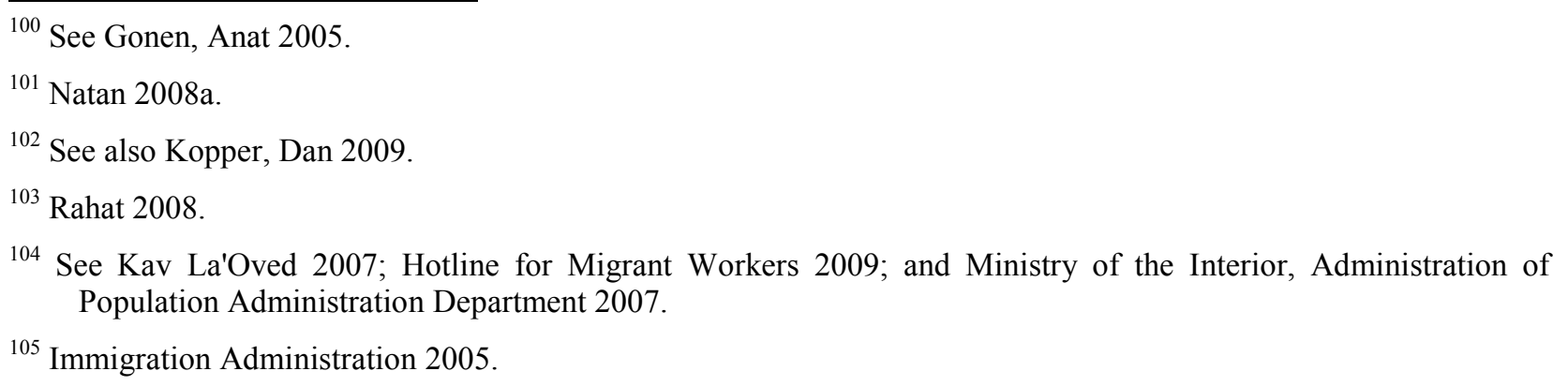


person must be brought within 4 days before an administrative court, called the Detention Inspection Court, which operates within the prison. The Court can decide to keep the foreign worker in detention until he/she is deported, or release the detainee on bail until he/she leaves the country independently. The detained person must be given 72 hours to appeal his/her deportation. Finally, all procedures must be carried out in a language that the detained person can understand.

63. Foreign workers in detention can ask to continue working in Israel and to be released to find a new employer. Workers in detention who are not entitled to be released and can expect deportation are workers without a valid passport, workers who worked in a sector other than the one for which they have a permit, those who have been detained multiple times for not having a permit, and those who have been in Israel for over 4 years and 3 months, i.e., those in the last year of their potential legal stay limit.

64. According to the ITL report, in 2007 the number of detained and deported workers declined from the years 2003-2005. At the same time, increasing numbers of foreign workers have been re-assigned to other employers in the same sector after detention. In practice, the Ministry of the Interior does not allow the reassignment of workers between sectors. According to the report, the data reflect the "Closed Skies" policy, which aims to reduce the number of foreign workers who enter Israel and re-assign those who are already in the country ${ }^{106}$. In addition, the Knesset Information and Research Center (MMM) published a report which shows that during the last few years the government implemented re-assignment and regularisation procedures only for those foreign workers who had entered with work permits and who meet the "Closed Skies" criteria ${ }^{107}$.

65. However, re-assignment and regularisation can still take place after the worker has been detained. Organisations like HMW and Kav La'Oved cast doubt on the accuracy of government reports regarding reassignment and provide evidence that foreign workers are still being detained under the binding policy, even though the High Court has ordered its abolition. ${ }^{108}$ According to Sigal Rosen from the HMW, there are frequent cases in which homecare workers are detained because the employer did not pay the fees and they are then reassigned after detention to the same employer. ${ }^{109}$

\section{Pregnancy, Maternity and Children of Undocumented Foreign Workers ${ }^{110}$}

66. Women without medical insurance are not entitled to health care during pregnancy, aside from Family Health Clinic services ("Tipat Halav") provided by the municipalities. It is possible to purchase a medical insurance policy from a private company at any time, even during pregnancy, but in this case the insurance company is not obliged to cover monitoring services during the pregnancy. Women without a work permit can purchase medical insurance.

67. When a foreign worker, regardless of her legal status, gives birth, she should get coverage for the hospital stay as well as a one-time birth payment (maternity grant). Female workers without permits are also entitled to paid maternity leave from National Insurance. After birth, there is a subsidised program operated by the HMO Mehuchedet whereby the government covers half the cost of the child's medical insurance and the parents bear the cost of the other half.

\footnotetext{
${ }^{106}$ Bar Zuri 2008.

${ }^{107}$ Natan and Tzwebner 2009.

${ }^{108}$ See Knesset Committee for the Examination of the Problem of Foreign Workers 2008.

${ }^{109}$ Interview with Sigal Rosen, HMW, 31 May 2009.

${ }^{110}$ See Kav La’Oved 2010.
} 
68. Children of undocumented foreign workers are entitled to health insurance and are subject to compulsory free education, although there are limits on their ability to realise their rights. Tel Aviv Municipality has been the most active and straightforward authority in incorporating large number of foreign workers' children, mostly undocumented. It was not until May 2001, following a joint initiative by the municipality, members of the Knesset's Education Committee, and the school's principal, that the Ministry of Education took responsibility for applying the Compulsory Education Law to foreign children ${ }^{111}$.

69. Finally, in June 2005, after an intensive campaign by local NGOs, the government decided to naturalise a limited number of children and their families: 562 out of the 862 requests submitted to the Ministry of the Interior were accepted; as a result 2000 children and their family members acquired status in Israel (permanent residence for children and citizenship upon enlisting in the IDF, and temporary residence for their relatives that would eventually turn into permanent residence). The children and their families who did not meet the criteria continue to be under the constant threat of deportation.

\section{Recent policy changes and pressing issues}

\section{Closed Skies}

70. A most significant policy change took place with the enactment of the "Closed Skies" policy in $2002,{ }^{112}$ which marked a shift in the "policy paradigm" that seeks the replacement of foreign workers by Israeli low-skilled workers and is apparently being "pushed" mainly by the Treasury. This policy has fulfilled at least two main goals, albeit partially and not in full compliance with its main declared intentions: 1. To reduce the number of foreign workers in Israel and replace them with low-skilled Israeli workers. This goal has been fulfilled in the construction sector, though the reduction in the number of foreign workers has been accomplished also by re-integrating Palestinian non-citizen workers from the Palestinian Authority. ${ }^{113}$ 2. To reduce the number of undocumented foreign workers by means of deportation. The results have been less clear in the field of re-assigning foreign workers who are already in the country with permits or whose permits expired either because they overstayed or due to the binding system. Re-assignment was an intrinsic part of the Closed Skies policy.

71. A continuation of the same "paradigm shift" is to be found in the report submitted in 2008 by the inter-ministerial Committee for the Formulation of Labour Migration Policy ${ }^{114}$. Submitted within the framework of a "Social-Economic Agenda for 2008-2010" that prioritises local employment and poverty reduction in Israel, the report advocates the advantages of the employment of unskilled Israeli workers,

\footnotetext{
${ }^{111}$ Kemp and Raijman 2004, p. 41.

112 See the Ministry of Interior 2009c.

Ministry of Interior, administration of Population Administration Department 2008.

${ }^{113}$ It should be noted that the re-integration of Palestinian workers from the Palestinian Authority in the Israeli labor market is not part of an official governmental policy and therefore has not been the subject of open debate. Work permits for Palestinians from the PA have been intermittently issued since 1996 and decisions on that respect have varied in accord to evaluations of the military on the security situation. Thus, for instance, following the second intifada in October 2000, the number of permits issued to Palestinian workers was reduced to zero and more recently, following the relaxation of closure policies, the number of permits has increased. The Eckstein Committee's report favors the employment of Palestinian workers in the construction sector as a short-term solution to labour shortages and a means for reducing the number of foreign workers in the Israeli labour market. For data on the share of Palestinian workers in the Israeli labor market, see Bank of Israel 2007.

${ }^{114}$ Eckstein 2008.
} 
while taking into consideration the specific benefits of employing foreign workers in the care-giving sector as well as in agriculture in remote areas.

72. In accordance with the Committee's recommendations, the government decided to put an end to the employment of foreign workers in the construction and industry sectors by 2010. Among other (unprecedented) recommendations submitted by the Committee is modifying the criteria for issuing permits to employ foreign care-givers, so as to limit eligibility to those whose level of disability requires 24-hour home care. The Eckstein Committee expects thereby to narrow the allocation of permits and encourage the employment of Israeli workers in an enlarged part-time home-care sector. ${ }^{115}$

\section{The following changes have not been fully implemented on the ground:}

\section{The Recruitment Process and the fight against trafficking for labour}

73. Recent efforts to eliminate the exploitation of workers led to a series of government decisions aimed at designing a different recruitment method, the latest of which was Decision 3996 in August $2008 .{ }^{116}$ Under the new arrangements, the Israeli government will sign bilateral agreements with sending countries, allowing the IOM to perform and supervise the recruitment process, instead of private agencies. In addition, the Israeli Consulate in the sending country will have comprehensive guidelines to perform the screening process abroad and will give potential workers extensive information about their rights and duties once in Israel ${ }^{117}$. The NGOs that participated in the meeting at the Knesset Committee on Foreign Workers on 20 January 2009 also suggested appointing a special representative who will be in charge of the new procedure and will collect information about recruitment fees charged workers in agencies abroad. ${ }^{118}$

74. The government decisions on the new recruitment arrangements have, however, still not been implemented. The Ministry of Foreign Affairs established contact with the government of Thailand with regard to a bilateral agreement, but so far this initiative has had no substantial results. In addition, negotiations with the IOM have stalled, as the concerned Ministries did not follow the requirements of the organisation $^{119}$. At the beginning, the delay in applying the IOM recruitment method was blamed by representatives of Israel's agriculture lobby on the IOM's alleged lack of experience and of an effective recruitment mechanism. Then the IOM required that its mediation role be carried out and backed by the signature of a bilateral agreement between Israel and Thailand, to which the Israeli Ministry of Foreign Affairs has raised an objection in principle in the past and has remained reluctant in the present ${ }^{120}$. Currently the delay stems from the need to establish a quota of agriculture foreign workers that will be recruited through the IOM. For that purpose the Israeli government needs to estimate the number of workers required and the purposes and length of their stay. At this stage, it is the Israeli government that is blocking implementation of the new arrangements ${ }^{121} .{ }^{122}$ The ITL in the meanwhile has declared that it will

\footnotetext{
${ }^{115}$ See Israel Government 2007; 2007a; 2006.

${ }^{116}$ See Israel Government 2008a and Natan 2009a.

${ }^{117}$ Natan 2008b.

${ }^{118}$ See Knesset Committee for the Examination of the Problem of Foreign Workers. 2009a.

${ }^{119}$ Natan 2008b.

${ }^{120}$ Natan $2008 b$.

${ }^{121}$ Natan 2009b, p. 3.

${ }^{122}$ Natan, 2009b.
} 
boost the enforcement of regulations in the screening process, especially the workers' required level of English (see previous discussion in the section on Pre-screening and exclusionary criteria).

\section{Abolishing the binding system in the care-giving and agriculture sectors and implementing a non- discriminatory arrangement based on free labour}

75. Following the ruling of the High Court of Justice in 2006 that ordered the replacement of the binding arrangement, in September 2006 the government announced that a new arrangement had been formulated for the care-giving and agriculture sectors. In the home-care sector it was not until two years later, in September 2008, that the reform was implemented, albeit only partially ${ }^{123}$. As its full implementation was protracted and no details were published about the new arrangement that were to replace the binding system, in November 2008 the High Court of Justice held the State in contempt of court and demanded that full details of the new arrangements be announced within 30 days ${ }^{124}$.

76. Under the new system ${ }^{125}$, workers have to register in private agencies and will be able to change employers. In the care-giving sector, the worker will be bound to the private agency during the first year of his/her employment, and there will be a preference for foreign workers who already reside in Israel. In September 2008, the ITL submitted the following procedures to be included in the new arrangements in the care-giving sector: private agencies will deposit up to NIS 500000 (per agency) to ensure workers' rights; a database of workers who already reside in Israel will be established in order to reduce the number of new workers recruited (the registration to the database has started and workers are required to register by March $\left.2009^{126}\right)$; etc.

77. The new method is supposed to enable workers to enjoy better conditions and higher wages, to better match employers' needs and workers' abilities, and to improve the supervision of employers. However, the report of the inter-ministerial Committee raises several concerns: one is that the new arrangements will increase the illegal recruitment fees charged workers, as any increase in employment fees is customarily "devolved" from employers and agencies to the workers; and second is that workers "will easily leave" patients with serious disabilities who are highly dependent on their care-giver ${ }^{127}$. The latter concern seems to be based on entrenched perceptions among Israeli policy makers and employers that tend to privilege the control of workers once inside Israel, through the binding procedure for instance, along with a lack of or lenient controls from the outside, including unenforced or no quotas. The reluctance to forego the binding arrangement in the home-care sector also stems from the consensual assumption that this is a drastically different employment sector than others, and therefore requires personal binding. I believe that effectively closing the skies to the superfluous recruitment of foreign workers on the one hand (by eliminating the private international brokerage, conducting strict disability eligibility tests and informing workers about the work conditions prior to arrival, for example) and ensuring good working conditions and positive incentives (for instance, substantially better wages based on NII subsidies) for foreign workers who work with seriously disabled people, on the other, would do much to deal with the Eckstein Committee's concerns in this regard.

\footnotetext{
${ }^{123}$ Natan 2009a.

${ }^{124}$ Natan 2008c, p. 4.

${ }^{125}$ Natan 2008c.

${ }^{126}$ HMW and Kav La'Oved have already expressed their dissatisfaction with this latest instruction. They argue that limiting the registration with a deadline undermines the whole purpose of the new arrangement to regularise the status of undocumented workers and re-assign them. One paradoxical case: what should a foreign worker do if his/her employer passes away after the deadline?
}

${ }^{127}$ Eckstein 2007, p. 39. 
78. Under the new arrangements, the employers, who in practice are disabled people with limited resources, are required to pay private agencies fees on a regular basis. There are two types of fees: a onetime hiring fee of up to NIS 2000 (USD 500) and a monthly fee of NIS 70 (USD 17). However, there are recurrent complaints that agencies collect hiring fees "retroactively", i.e., also for workers who are already in place and for renewing permits (the latter is explicitly forbidden by MITL procedures) ${ }^{128}$. In addition, elderly disabled are to pay a one-time employment permit request fee of NIS 250 (USD 62) and an annual employment fee of NIS 268 (USD 67) (ibid). Except for a small group of extremely disabled people, the NII subsidies have not increased after the introduction of the new arrangement's fees.

79. Therefore, the Knesset Information and Research Center report recommends re-examining the ability of this population in need to actually bear the expenses ${ }^{129}$. In the meeting of the Committee on Foreign Workers in December $2008^{130}$, representatives of employer organisations in the care-giving sector expressed these misgivings. At that same meeting, the representatives of HMW and Kav La'Oved reported that despite the decision to encourage the employment of workers who are already in Israel and to create a workers' database, in practice large numbers of foreign workers in the care-giving sector are still being detained as a result of being bound to one employer. According to a report from February 2009, the collection of new fees by the private agencies was the only part of the new arrangement in the home-care sector that was fully applied ${ }^{131}$.

Organisational changes: the new Population, Immigration and Border Passage Authority (PIBPA) in the Ministry of the Interior

80. The full significance of the jurisdictional transfer to the newly established Population, Immigration and Border Passage Authority (PIBPA), is still to be seen. Presumably, as the jurisdictional reorganisation would also involve the transfer of personnel, it could lead to reinforcing the area of inspections. All through the 1990s and 2000s this area has been understaffed, which also reflects that labour law enforcement for foreign workers and citizen workers alike is not at the top of the MITL's priorities. During the 1990s and well before the establishment of the Immigration Police in 2002, the MITL (then the Ministry of Welfare and Labour) inspection division focused its limited resources and efforts on finding undocumented foreign workers, and not on enforcing labour protections (see Israeli State Comptroller Reports). The PIBPA has been founded on the basis of the same personnel who created, directed and operated the Immigration Police and the Population Division at the Ministry of the Interior, so there should be no expectation that they will transform their views on these issues overnight. "Inspections" and labour law compliance will not be their immediate priority, even though they should be.

81. I would go further in my recommendations as to how the system could profit from the jurisdictional reorganisation. My suggestion would be to utilise some of the 80 positions recovered by the MITL to create a special division at the National Employment Service dedicated to the management of the brokerage between foreign workers and Israeli employers (job placement, etc.) that nowadays is performed by private agencies. Conversely, the proposed NES Foreigners Division could be located within and operated by the PIBPA, whose main mandate is to manage the data and issues involved in the recruitment, employment and residence of foreign workers in Israel. The newly created PIBPA could be utilised as a means to truly reform the management of the labour migration scheme so as to involve the government (public agencies) directly. A great part of the resources dedicated to inspecting and monitoring private agencies could be redirected to the new public NES, and its funding could rely on state subsidies and on

\footnotetext{
${ }^{128}$ Natan $2009^{\mathrm{a}}$.

${ }^{129}$ Natan 2008c.

${ }^{130}$ See Knesset Committee for the Examination of the Problem of Foreign Workers 2008.

${ }^{131}$ Natan $2009^{\mathrm{a}}$.
} 
fees paid by employers of foreign workers, which would be lower than those paid nowadays. Of course, the state would not be seeing much revenue in the form of "license fees", etc.

\section{Pressing changes and reforms to be made to current policy}

82. The Israeli temporary labour migration program is characterised by the strong dependency of certain sectors on temporary foreign workers; the conspicuous disengagement of governmental agencies from direct involvement in the recruitment of foreign workers, the inspection of their work conditions, the effective enforcement of labour laws, and the provision of services for foreign workers; a strong emphasis on making the residence of labour migrants temporary (fueled by explicit ethno-demographic considerations), coupled with a lengthy and sometimes indeterminate prolongation of possible stays (up to 63 months and potentially more); and lastly, well-entrenched client politics that guide the policies on quota setting, permits and the allocation of employer subsidies. Client politics have not subsided, even though the labour migration system in Israel is well past its initial phase.

83. While there is nothing extraordinary or exceptional in any of these characteristics, it is their combination that renders the Israeli scheme ill-conceived and non-viable in its present shape (from whichever angle we define viability). Recent government decisions that seek to overcome the distorting effects of the scheme on the Israeli labour market, while tempering deep-rooted norms that consistently violate workers' labour and human rights are heading in the right direction. However, they are also doomed to fail if the scheme is not substantially revised as a whole rather than through a patchwork of focalised and segmented measures, as seems to be the case now. Thus, while my recommendations take into account realistic possibilities and power constellations (some of the recommendations are already "in the air"), they are also aspirational, as they refer to my understanding of how the system in Israel should look in order to keep pace with OECD standards. I focus on three main dimensions:

1. The increased involvement of government and public agencies in the recruitment (international intermediation), pre-screening and job placement of foreign workers and the elimination of private forprofit agencies' involvement.

84. At the international recruitment stage, Israel should be directly involved by implementing without further delay the signature of bilateral agreements with each and all of the sending countries. To that end, it should announce that further recruitment will be allowed only within the framework of bilateral agreements. There is no need for "pilot" experiments or any other excuse for procrastination. The advantages of bilateralism for all stakeholders are well known and proven.

85. Effective governmental involvement should be seen at the pre-screening process through Israeli consulates, and consular officers for labour migration issues should be appointed in sending countries so as to ensure that screening follows official guidelines and that no illegal recruitment fees are collected. Ensuring that workers are trained in their home countries could also be an advantage of the bilateral agreements.

86. Current private international brokerage could be replaced by the IOM mechanism (as currently suggested in the agriculture sector) or, if that is not possible, through joint selection committees or procedures agreed upon in the respective bilateral agreement. The above-mentioned recruitment mechanisms, operated by public agencies (this could be from the PIBPA, NII, the Ministry of Construction and Infrastructure, or the MITL Foreign Workers Division), could be applied in all sectors that employ foreign workers. Conversely, when and if no public agencies are found to be eligible, licensed non-profit agencies (these could be professional associations or NGOs that specialise in labour, welfare and health care issues) could be created or operated for that purpose. The field of service provision for foreign workers in Israel is full of examples of non-profit organisations and "hybrid" public-private agencies (i.e., 
Mesila in Tel Aviv) that were created to that effect and proved highly effective in replacing both governmental and market organisations.

87. The main idea is to turn off the main engine behind the superfluous recruitment of foreign workers and their eventual trafficking: profits achieved through the illegal and inflationary collection of fees. So far, all the new employment arrangements implemented in Israel have stumbled on the same point: profit-seeking that degenerates into serious violations and the lack of enforcement against violators. Introducing public agencies that collect minimum fees (the IOM proposes to collect USD 300 from Thai workers who wish to work in Israel in agriculture, as opposed to USD 8000 that the workers pay today to private international brokers) will render it difficult for private agencies to compete and survive.

88. Eliminating the role of profit-seeking private agencies (brokers) in the area of job placement (home care and agriculture) and foreign workers' employment (construction) within Israel should also be a policy objective. In home care today, the patient is held to be the direct employer, the subsidies are paid by the NII, reassignment is effected through the Ministry of the Interior, and NGOs like HMW are pretty much involved in bringing foreign workers to the registry and searching for new suitable employers (as they were, by the way, in the case of job placement for humanitarian migrants from Sudan, Darfur and Eritrea). At the same time, as reports on illegal fee collection accrue, public resources are spent on inspecting a seemingly superfluous mediating tier of licensed agencies. Policy makers should be asked, to what effect and purpose is the employment of foreign workers conditioned on the mediation of private agencies?

89. In sum, transferring the recruitment and employment functions from private for-profit agencies to public or third-sector organisations could facilitate the following:

1. Solving current problems in human trafficking and the violation and exploitation of workers. It will shorten the length of the long stays required to pay off the high mediation fees and costs.

2. Canceling the incentive to bring in superfluous workers (no mediation fees).

3. Lowering the fees that employers have to pay to brokers in order to find workers abroad (only costs, minimum overhead or no overhead if operated by governmental organisations).

4. Achieving the financial viability of the public or hybrid organisations through the collection of processing and cost fees, both paid by the employer; fines will be collected directly from private employers that violate workers' rights, and not from broker agencies that either do not pay (political power) or devolve the costs to clients (workers and direct employers alike).

2. Labour market demand assessment and tests: both are crucial elements in ensuring the establishment both of adequate quota policies that do not distort the local labour market and of a level of work permits that satisfies the market needs. The Israeli scheme lacks both periodical and rigorous market assessment of the sectors involved, and where such an assessment exists, it seems to be perfunctory. More importantly, no necessary steps are taken to advertise job demand before the employer can apply for authorisation to hire foreign workers.

90. Current policy proposals suggest extending restrictive discretionary criteria to whole sectors, such as catering and restaurants and construction ("expert workers"), or restricting foreign employment to certain geographical regions (agriculture). However, these seem to be based less on labour market assessment and more on wishful thinking (disciplining the native labour force and employers).

91. Moreover, these proposals, articulated time and again by government officials and politicians, may lead to unintended negative effects. In the years following the "Closed Skies" policy, a top-down 
discourse that scapegoats labour migrants for diverse social illnesses has evolved, while singling them out as "the cause" of unemployment and of a long list of "social threats." One negative phenomenon that has not (yet) developed in Israel around the issue of labour migrants is an anti-foreigner mobilisation. To be sure, xenophobic pronunciations have from time to time been voiced out loud by politicians from ultraorthodox religious parties and street bureaucrats from the Ministry of the Interior and the Immigration Authority (Police). However, no party has incorporated an anti-foreigner platform in its agenda, nor has an anti-immigrant grassroots mobilisation taken place. It is policy makers' responsibility to prevent this from happening, especially in the face of the new economic downturn, the unforeseen and unsolicited influx of humanitarian migrants from Africa that caught the public eye, and an intra-state struggle between different agencies (i.e. Treasury, CBI and Ministry of Agriculture, for instance) over the future and nature of labour migration programs in Israel.

3. Repealing the binding policy in accordance with the ruling of the High Court of Justice in all sectors, by seeing that employer (or corporation) and employee registration will not be linked to residence and work permits. However, as long as foreign workers are still bound to private agencies, bonds ensuring foreign workers' rights must be forfeited in case of violations. In addition, workers who are already in Israel should not be detained. Rather, they should have the possibility to find a new work place within 3 months, which is the period stipulated, though not necessarily implemented, by the new procedure ${ }^{132}$. Reassigned foreign workers should stay in the same sector, although there should be a mechanism to allow inter-sector visa portability in exceptional cases.

92. Measures taken to re-assign workers who are already in Israel, such as a database for care-givers, should be accessible for workers in all sectors, with no deadlines for registration. Nowadays the database is only for foreign care workers with permits who are unemployed. The registry should be open to all workers.

4. Length of stay: the Israeli case is characteristic of the family of temporary programs designed to meet permanent labour demand while preventing migrants from settling in the country. In order to avoid both the violation of human rights involved in the indefinite continuation of a temporary status, and at the same time temper the ethno-demographic anxieties and social animosities that spring from the incorporation of unwanted immigrants, the status of "temporary" in Israel should be redefined and restructured in two complementary ways:

1. Upgrading temporariness: this can be attained through the adoption of various non-mutually exclusive measures such as:

a) Opening effective channels for family reunification for workers legally staying for periods longer than one-and-a-half consecutive years.

b) Allowing the free entry and exit of foreign workers who are to stay longer than one year, with renewable permits.

c) Opening a channel for stable residence rights or citizenship acquisition for foreign workers who stay five years on renewable permits (in Israel, this would apply to elderly home care). A requirement could be introduced to demonstrate employment or self-sufficiency. The latter measure was proposed once by former Minister of the Interior Avraham Poraz, which advocated opening channels for permanent residence for foreigners with "added value" (in sports, music and the arts), and foreign home care workers who legally worked in Israel for

${ }^{132}$ Natan 2009a. 
long periods of time. Poraz also initiated a reform that would result in the eventual naturalisation of migrant workers' children ${ }^{133}$.

2. "Downgrading" or limiting temporariness: limit the length of the work and the residence permit. In order for a permit to be "temporary", it should not extend for more than one-and-a-half years, non-renewable. Seasonal employment schemes could be applied to agriculture. This proposal would be viable only if commuting and mediation costs are low enough to render the arrangement suitable for both the workers and employers.

${ }^{133}$ See Kemp 2007. 


\section{REFERENCES}

Bank of Israel. 2007. "Annual Report". http://www.bankisrael.gov.il/deptdata/mehkar/doch07/eng/pe_5.pdf

Bar Zuri, Roni. 2009. "Undocumented Foreign Workers Who Were Deported from Israel in 2008." The ITL's Research Administration (Hebrew) http://www.tamas.gov.il/NR/rdonlyres/9DEDF646-1ABD-40C2-A80E 17C1C542EB91/0/9079.pdf

Bartram, David V. 1998. "Foreign Workers in Israel: History and Theory." International Migration Review, 32: 303-325.

Berman, Jonathan. 2007. "Freedom Inc. - Binding Migrant Workers to Manpower Corporations in Israel." Kav La'Oved and Hotline for Migrant Workers. http://www.kavlaoved.org.il/userFiles/news1075_file.pdf

Central Bureau of Statistics (CBS). 2008. "Statistical Abstract of Israel 2008."

Central Bureau of Statistics (CBS). 2008. "Press Release: Demographic Situation in Israel-2007." (Hebrew). http://www.cbs.gov.il/reader

Eckstein, Zvi. 2007. A Report by the Inter-Ministerial Committee for the Formulation of Labour Migration Policy. Jerusalem: State of Israel (Hebrew).

Gilat, Mordechai, and Michal Grayevski. 2000 "Bribery, deception, and threats," Yediot Aharonot, weekend supplement, 8 Dec. p. 4-7 (Hebrew).

Gonen, Anat. 2005. "Thai Workers in Israel - the Silence Connection." Kav La'Oved (Hebrew). http://www.kavlaoved.org.il/media-view.asp?id=65

Gottlieb, Daniel. 2002. "The Effect of Migrant Workers on Employment, Real Wages and Inequality: The Case of Israel." Bank of Israel (Hebrew).

http://www.bankisrael.gov.il/deptdata/neumim/neum121e.pdf.

High Court of Justice (HCJ) 10843/04 Kav LaOved v. the Ministry of the Interior (Hebrew).

Hon, Daniel Safran. 2008. "Commission: A Report on the Situation of Foreign Workers in the Care-giving Sector 2007-2008." Kav La'Oved (Hebrew).

http://www.kavlaoved.org.il/UserFiles/news1982_file.doc

Hotline for Migrant Workers. 2009. "Rights of Foreign Workers in Detention" (Hebrew).

http://www.hotline.org.il/hebrew/rights\&info/detainees.htm

Hotline for Migrant Workers. 2004. The Implementation of the Endorn Report: Concern About Human Trafficking in the State of Israel. Hotline for Migrant Workers, The Association for Civil Rights in Israel, The Law and Welfare Program at Tel Aviv University Law Faculty, and Adva Center. 
Israeli Labour Court (ILC) 270/08 Serafima Bodeic v. Doni Hana (Hebrew).

Immigration Administration. 2005. "Law of Entrance to Israel, 1952." (Hebrew). http://www.hagira.gov.il/ImmigrationCMS/Laws/l1.htm

Interministrial Committee. 2004. "Planning a System of Employing Foreign Workers in Iarael and conditions of Distributing Foreign Workers Employing Licenses." Ministry of Industry, Trade and Labour (Hebrew). http://www.moital.gov.il/NR/rdonlyres/08BCE686-C3B2-474C-B92C2DAF35A4FD41/0/20047211.pdf

Israel Government. 2008. "Law Proposals." (Hebrew). http://www.knesset.gov.il/Laws/Data/BillGoverment/418/418.pdf

Israel Government. 2008a. "Government Decisions no. 3996: Government Policy in the Subject of NonIsraeli Workers and Enlargement of Work Possibilities of Israelis." (Hebrew) http://www.pmo.gov.il/PMO/Secretarial/bud/des3996.htm

Israel Government. 2007. "Recommendations of the Committee of Agriculture Export Encouragement Foreign Workers Employment." (Hebrew) http://www.pmo.gov.il/PMO/Archive/Decisions/2007/02/des1205.htm

Israel Government. 2007a. "Government Decisions no. 1205: Setting Quotas and Employment Conversion for Foreign Workers." (Hebrew)

http://www.pmo.gov.il/PMO/Archive/Decisions/2007/02/des1205.htm

Israel Government. 2006. " Law Proposals." (Hebrew). http://www.justice.gov.il/NR/rdonlyres/8E8574FCCAE7-44B0-847F-06B8AF36F5D0/5337/254.pdf

Israel Government. 2006a. "Enlargement of Work Possibilities of Israelis." (Hebrew) http://www.pmo.gov.il/PMO/Archive/Decisions/2007/02/des1205.htm

Kav La'Oved. 2010. "Information for pregnant non-Israeli women." http://www.kavlaoved.org.il/UserFiles/rights46_file_he.doc (accessed Jan. 17, 2010).

Kav La'Oved. 2008. "Recruitment Fees Charged From Domestic Care-Givers in Israel."

Kav La'Oved. 2007. "Rights of Foreign Workers in Agriculture." (Hebrew) http://www.kavlaoved.org.il/UserFiles/rights23_file_he.rtf

Kemp, Adraiana, and Rivka Raijman. 2008. Foreigners and Workers: The Political Economy of Labor Migration in Israel. Bney Brak: Hakibbutz Hamehuchad and Jerusalem: Van Leer Institute of Jerusalem (Hebrew).

Kemp, Adriana. 2007. "Managing Migration, Reprioritizing National Citizenship: Undocumented Labour Migrants' Children and Policy Reforms in Israel." Theoretical Inquiries in Law 8(2): 663-691.

Kemp, Adriana, and Rivka Raijman. 2004. "Tel Aviv is Not Foreign to You: Urban Incorporation Policy on Labour Migrants in Israel." International Migration Review, Vol. 38,:26-51.

Knesset Committee for the Examination of the Problem of Foreign Workers. 2009. "Protocol No. 66." (Hebrew) http://www.knesset.gov.il/protocols/heb/protocol_search.aspx 
Knesset Committee for the Examination of the Problem of Foreign Workers. 2009a. "The Foreign Affairs Ministry's treatment of Issues Related to Foreign Workers." (Hebrew)

http://www.knesset.gov.il/protocols/heb/protocol_search.aspx

Knesset Committee for the Examination of the Problem of Foreign Workers. 2008. "Examination of the Nursing Reform." (Hebrew) http://www.knesset.gov.il/protocols/heb/protocol_search.aspx

Knesset Committee for the Examination of the Problem of Foreign Workers. 2002. "Treatment of Thousands of Chinese Workers Brought to work in Israel." (Hebrew) http://www.knesset.gov.il/protocols/heb/protocol_search.aspx

Knesset Committee for the Examination of the Problem of Foreign Workers. 2002a. "Government Policy on: Comprehensive Banishment of Foreign Workers."

http://www.knesset.gov.il/protocols/heb/protocol_search.aspx

Kopper, Dan. 2009. "2008 Report - Employment in Agriculture." KavLaOved (Hebrew).

http://www.kavlaoved.org.il/media-view.asp?id $=2252$

Korazim, Malka, Tali Goren, and Ronit Niran. 2002. "Home Care Workers for the Elderly: Characteristics, Role Perception, and Patterns of Work and Employment." The Myers-JCD-Brookdale Institute, in cooperation with the National Insurance Institute (Hebrew).

http://brookdale.jdc.org.il/?catid=\{EAE5F7CB-6930-4336-BD93-1B02A618E448\}\#\{245EBA2C1717-4ACA-9976-CC96E563B015\}.

Laissez Passer. 2009. "Policy of Arranging the Status of Common-Law Marriage being strictened." (Hebrew) http://www.mehagrim.org/2009/02/blog-post_16.html

Levenkron, Naomi. 2007. "The Legal system Dealing with Trade in Humans in the Year 2007" Hotline for Migrant Workers (Hebrew). http://www.hotline.org.il/hebrew/publications/publications072108.htm

Livnat, Yuval. 2008. "Women of the World, Unite." Laissez Passer website (Hebrew). http://www.mehagrim.org/2008/10/blog-post_12.html

Meiri, Oron, Meiron Rapoport and Ofer Petersburg. 2001. "You've got your own unemployed, what do you need us for?" Yediot Aharonot, weekend supplement, 7 Dec. p. 18-22 (Hebrew).

Michaeli, Reut. 2008. "Lecture about Family Reunification and Mixed Marriages." Hotline for Migrant Workers. http://www.hotline.org.il/english/publications/mixed_marriages.htm

Ministry of Finance - Spokesman Department. 2002. "Economic Policy for 2003: Budget Composition and Structural Changes." (Hebrew)

http://dover.mof.gov.il/Mof/Dover/MofDoverTopNav/MofDoverSubjects/MofDoverSubjects_2002/M ofDoverSubjects_2002_11/Subject2397_2002_11_20.htm

Ministry of Industry, Trade and Labour. 2009. "Foreign Workers Rights Handbook." (Hebrew) http://www.tamas.gov.il/NR/rdonlyres/3E8413EA-F5FD-45EB-8CD75964EC8E4B1D/0/hebrewn.pdf

Ministry of Industry, Trade and Labour. 2008. "Update of Fees and Payments for the year 2009" (Hebrew). http://www.moital.gov.il/NR/exeres/BD78A51F-86A8-409D-BCBC-5162997D7886.htm 
Ministry of Interior. 2009. "Procedure of Ordering General Foreign Worker and License Extension." (Hebrew)

http://www.moin.gov.il/Apps/PubWebSite/publications.nsf/All/8CF6C0E66A590C8A422570AD0043

F769/\$FILE/Publications.3.0001-2024.9.09\% נסיון.pdf?OpenElement

Ministry of Interior. 2009a. "Procedure of Treatment of Pregnant Foreign worker and Foreign Worker That have Given Birth in Israel." (Hebrew)

http://www.moin.gov.il/Apps/PubWebSite/publications.nsf/All/B96025D3EC6D1EA9422570AD0046 3773/\$FILE/Publications.3.0023-1.8.2009.pdf?OpenElement

Ministry of Interior. 2009c. "'Closed Skies' Procedures." (Hebrew) http://www.moin.gov.il/Apps/PubWebSite/publications.nsf/All/C5BE5BDC0AD17AECC2257503004 E368C/\$FILE/Publications.1.0008-19.1.09.pdf?OpenElement

Ministry of Interior, Administration of Population Department. 2008. "Arrangement to the Year 2008 in the Subject of Foreign Workers." (Hebrew)

http://www.moin.gov.il/Apps/PubWebSite/mainmenu.nsf/4DF815EA4AC4E503C2256BA6002EE7

32/41F69121FA6EF637C22573D9003DDC8A/\$FILE/News.pdf

Ministry of the Interior, Administration of Population Department. 2007. "Enforcement Regulations" (Hebrew) http://www.moin.gov.il

Naon, Denise, Jenny Brodsky, Shlomit Ben-Noon, Shirli Resnizky, Brenda Morginstin, Ramsees Gara, and Miriam Schmeltzer. 2004. "Disabled Elderly Recipients of Cash and In-kind Benefits." The Myers-JCD-Brookdale Institute, in cooperation with the National Insurance Institute (Hebrew). http://brookdale.jdc.org.il/?catid $=\{172 E 8558-E B E 8-4186-88 F 8-830682 F 997 C 0\} \#\{B 8 B 502 B 7-$ 7E0A-4A17-8284-9E0AF4D4470D\}

Natan, Gilad, and Sarah Tzwebner. 2009. "Data on foreign workers and regularization procedures." The Knesset Information and Research Center (MMM) (Hebrew).

Natan, Gilad. 2009a. "Foreign Workers in Israel: Central Issues." The Knesset Information and Research Center (MMM) (Hebrew). http://www.knesset.gov.il/mmm/data/docs/m02210

Natan, Gilad. 2009b. "Treatment of the Ministry for Foreign Affairs in Issues Related to Foreign Workers." The Knesset Information and Research Center (MMM) (Hebrew).

http://www.knesset.gov.il/mmm/data/pdf/m02209.pdf

Natan, Gilad. 2008a. "The Government Decision to Increase the Quota of Foreign Workers in the Agriculture Sector." The Knesset Information and Research Center (MMM) (Hebrew). http://www.knesset.gov.il/mmm/data/docs/m02109.doc

Natan, Gilad. 2008b. "The Ministry of Foreign Affairs' Treatment of Labour Migration Issues." The Knesset Information and Research Center (MMM) (Hebrew). http://www.knesset.gov.il/mmm/heb/MMM_Results.asp?CatId=9

Natan, Gilad. 2008c. "Examination of the New Employment Method in the Care-giving Sector." The Knesset Information and Research Center (MMM) (Hebrew). http://www.knesset.gov.il/mmm/data/docs/m02167.doc 
Natan, Gilad. 2007a. "Cancellation of Quotas for Foreign Workers in the Hotel Sector in Eilat." The Knesset Information and Research Center (MMM) (Hebrew). http://www.knesset.gov.il/mmm/data/docs/m01722

Natan, Gilad. 2007b. "Problems in the new employment system in the construction sector." The Knesset Information and Research Center (MMM) (Hebrew). http://www.knesset.gov.il/mmm/data/docs/m01898.doc

National Insurance Institution. 2008. "Nursing Pension as money in Stead of as services." (Hebrew). http://www.btl.gov.il/Publications/booklet/hebrew_booklet/Documents/gimlat\%20seid_a4_2_3.pdf

Ofir, Yehezkel, Bat-Seva Holman, Haya Daskal, Orna Hiershfield, Nili Dror, and Solomon Havazelet. 2000." Foreign Workers in the Home Care Sector." Ministry of Labour and Welfare, The Manpower Planning Authority (Hebrew).

http://www.moital.gov.il/cmsTamat/Rsrc|koach|tichnun_koach_adam|tichnun_pirsumim|Pirs_maam arim $\mid x s i u d . p d f$

Physicians for Human Rights. 2007. "Your Right to Health Insurance: information about health insurance for migrant workers."

http://www.phr.org.il/phr/article.asp? articleid $=519 \&$ catid $=49 \& p c a t=49 \& l a n g=E N G$

Physicians for Human Rights. 2006. Principles of an Arrangement for the Employment of Migrant Workers in Israel. Physicians for Human Rights, The Association for Civil Rights in Israel, The Law and Welfare Program at Tel Aviv University Law Faculty, Commitment to Peace and Social Justice, Hotline for Migrant Workers and Adva Center.

Rahat, Ofer. 2008. "A Report on Foreign Workers Who Were Victims of Criminal Offences." Kav La'Oved (Hebrew). http://www.kavlaoved.org.il/UserFiles/news2078_file.doc

Semyonov, Moshe, and Noah Lewin-Epstein. 1987. Hewers of Wood and Drawers of Water: Noncitizen Arabs in Israeli Labor Market. Ithaca, N.Y. : ILR Press

Shaked, Dana. 2008. "Report on Activities Concerning Chinese Workers - 2008." Kav La'Oved. http://www.kavlaoved.org.il/searchexe.asp

Shaps, Marina. 2008. "At the End of 2007 in Israel: 110,000 Foreign Workers who Entered with Work Permits, and 90,000 who Entered as Tourists." Central Bureau of Statistics (Hebrew). http://www.cbs.gov.il/reader

Shaps, Marina. 2007. "Press Release: Data on Foreign Workers at the end of 2006." Central Bureau of Statistics (Hebrew).

http://www.cbs.gov.il/reader/newhodaot/hodaa_template.html?hodaa=200720139

Sinai, Ruth. 2008. "Israel's Nepalese workers declare independence." Haaretz. 4 June (Hebrew). http.www.haaretz.com/hasen/pages/990014.html

Sinai, Ruth. 2001. "Progress in the investigation of the illegal allocation of permits to foreign workers," Haaretz, 2 Dec. p. A13 (Hebrew).

Sinai, Ruth. 2001a "Petitions against the results of a tender for 4,000 foreign workers," Haaretz, 19 Dec. 2001, A12 (Hebrew). 
Socio, Ann, and Dana Shaked. 2008. "A Report Prepared for a Meeting of the Committee on Foreign Workers: Deficiencies in the ITL's Enforcement." Kav La'Oved (Hebrew).

http://www.kavlaoved.org.il/UserFiles/news1940_file.doc

Tabibian-Mizrahi, Michal. 2004. "The Binding Agreement and its Alternatives." The Knesset Information and Research Center (MMM) (Hebrew). http://www.knesset.gov.il/mmm/data/docs/m00850.doc

Zohar, Hanna. 2008. "Exceptionalization of Nursing Workers from the Law of Work and Rest Hours." Kav La'Oved (Hebrew). http://www.kavlaoved.org.il/media-view.asp?id=1984

Zohar, Hanna. 2008a. "Slavery Under the Law" Ynet (Hebrew). http://www.ynet.co.il/articles/0,7340,L$3615631,00 . \mathrm{html}$

Zussman, Noam, and Dimitri Romanov. 2003. "Foreign Workers in the Construction Industry: Current Situation and Policy Implications." Bank of Israel Discussion Paper No. 2003.06 (Hebrew). 


\section{OECD SOCIAL, EMPLOYMENT AND MIGRATION WORKING PAPERS}

Most recent releases are:

No. 102 LABOUR MARKET AND SOCIO-ECONOMIC OUTCOMES OF THE ARAB-ISRAELI POPULATION Jack Habib, Judith King, Asaf Ben Shoham, Abraham Wolde-Tsadick and Karen Lasky

No. 101 TRENDS IN SOUTH AFRICAN INCOME DISTRIBUTION AND POVERTY SINCE THE FALL OF APARTHEID

Murray Leibbrandt, Ingrid Woolard, Arden Finn and Jonathan Argent

No. 100 MINIMUM-INCOME BENEFITS IN OECD COUNTRIES: POLICY DESIGN, EFFECTIVENESS AND CHALLENGES Herwig Immervoll (2009)

No. 99 HAPPINESS AND AGE CYCLES - RETURN TO START...? ON THE FUNCTIONAL RELATIONSHIP BETWEEN SUBJECTIVE WELL-BEING AND AGE Justina A.V. Fischer (2009)

No. 98 ACTIVATION POLICIES IN FINLAND

Nicola Duell, David Grubb and Shruti Singh (2009)

No. 97 CHILDREN OF IMMIGRANTS IN THE LABOUR MARKETS OF EU AND OECD COUNTRIES: AN OVERVIEW Thomas Liebig and Sarah Widmaier (2009)

No. 96 INCOME DISTRIBUTION AND SUBJECTIVE HAPPINESS: A SURVEY Claudia Senik (2009)

No. 95 LOOKING INSIDE THE PERPETUAL-MOTION MACHINE: JOB AND WORKER FLOWS IN OECD COUNTRIES

Andrea Bassanini and Pascal Marianna (2009)

No. 94 JOBS FOR IMMIGRANTS: LABOUR MARKET INTEGRATION IN NORWAY Thomas Liebig (2009)

No. 93 THE WELFARE EFFECTS OF SOCIAL MOBILITY Justina A.V. Fischer (2009)

No. 92 HOW EXPENSIVE IS THE WELFARE STATE? GROSS AND NET INDICATORS IN THE OECD SOCIAL EXPENDITURE DATABASE (SOCX)

Willem Adema and Maxime Ladaique (2009)

No.91 SHOULD PENSION SYSTEMS RECOGNISE "HAZARDOUS AND ARDUOUS WORK”? Asghar Zaidi and Edward Whitehouse (2009)

No. 90 GOING SEPARATE WAYS? SCHOOL-TO-WORK TRANSITIONS IN THE UNITED STATES AND EUROPE

Glenda Quintini and Thomas Manfredi (2009)

No. 89 LEGISLATION, COLLECTIVE BARGAINING AND ENFORCEMENT: UPDATING THE OECD EMPLOYMENT PROTECTION INDICATORS

Danielle Venn (2009)

No. 88 TOWARDS A FRAMEWORK FOR ASSESSING FAMILY POLICIES IN THE EU

Henning Lohmann, Frauke H. Peter, Tine Rostgaard and C. Katharina Spiess (2009)

No. 87 INVESTMENT RISK: IMPACT ON RETIREMENT INCOMES AND GOVERNMENT BUDGETS Edward Whitehouse, Anna Cristina D’Addio and Andrew Reilly (2009)

No. 86 PENSION REFORM IN CHILE REVISITED: WHAT HAS BEEN LEARNED? Augusto Iglesias Palau (2009)

Other series of working papers available from the OECD include: OECD HEALTH WORKING PAPERS 


\section{RECENT RELATED OECD PUBLICATIONS:}

JOBS FOR YOUTH: UNITED STATES (2009)

JOBS FOR YOUTH: POLAND (2009)

OECD EMPLOYMENT OUTLOOK: Tackling the Jobs Crisis (2009)

DOING BETTER FOR CHILDREN (2009)

SOCIETY AT A GLANCE - ASIA/PACIFIC EDITION (2009)

OECD REVIEWS OF LABOUR MARKET AND SOCIAL POLICIES: SLOVENIA (2009)

INTERNATIONAL MIGRATION OUTLOOK: SOPEMI (2009)

PENSIONS AT A GLANCE 2009: Retirement-Income Systems in OECD Countries (2009)

JOBS FOR YOUTH: FRANCE (2009)

SOCIETY AT A GLANCE 2009 - OECD Social Indicators (2009)

JOBS FOR YOUTH: AUSTRALIA (2009)

OECD REVIEWS OF LABOUR MARKET AND SOCIAL POLICIES: CHILE (2009)

PENSIONS AT A GLANCE - SPECIAL EDITION: ASIA/PACIFIC (2009)

SICKNESS, DISABILITY AND WORK: BREAKING THE BARRIERS (VOL. 3) - DENMARK, FINLAND, IRELAND AND THE NETHERLANDS (2008)

GROWING UNEQUAL? Income Distribution and Poverty in OECD Countries (2008)

JOBS FOR YOUTH: JAPAN (2008)

JOBS FOR YOUTH: NORWAY (2008)

JOBS FOR YOUTH: UNITED KINGDOM (2008)

JOBS FOR YOUTH: CANADA (2008)

JOBS FOR YOUTH: NEW ZEALAND (2008)

JOBS FOR YOUTH: NETHERLANDS (2008)

OECD LABOUR FORCE STATISTICS: 1987-2007 (2008)

JOBS FOR IMMIGRANTS (Vol.2): Labour Market Integration in Belgium, France, the Netherlands and Portugal (2008)

IMMIGRANT HEALTH WORKERS IN OECD COUNTRIES IN THE BROADER CONTEXT OF HIGHLY SKILLED MIGRATION (2008)

INTERNATIONAL MIGRATION OUTLOOK (2008)

OECD EMPLOYMENT OUTLOOK (2008)

OECD REVIEWS OF LABOUR MARKET AND SOCIAL POLICIES IN SERBIA (2008)

A PROFILE OF IMMIGRANT POPULATIONS IN THE $21^{\text {ST }}$ CENTURY (2008)

For a full list, consult the OECD On-Line Bookstore at www.oecd.org 